\title{
Enteric infections, diarrhea, and their impact on function and development
}

\author{
William A. Petri Jr., ${ }^{1}$ Mark Miller, ${ }^{2}$ Henry J. Binder, ${ }^{3}$ Myron M. Levine, ${ }^{4}$ \\ Rebecca Dillingham, ${ }^{1}$ and Richard L. Guerrant ${ }^{1}$
}

\begin{abstract}
${ }^{1}$ Center for Global Health, Division of Infectious Diseases and International Health, University of Virginia School of Medicine, Charlottesville, Virginia, USA. ${ }^{2}$ Fogarty International Center, NIH, Bethesda, Maryland, USA. ${ }^{3}$ Yale University, New Haven, Connecticut, USA. ${ }^{4}$ Center for Vaccine Development, University of Maryland School of Medicine, Baltimore, Maryland, USA.
\end{abstract}

\begin{abstract}
Enteric infections, with or without overt diarrhea, have profound effects on intestinal absorption, nutrition, and childhood development as well as on global mortality. Oral rehydration therapy has reduced the number of deaths from dehydration caused by infection with an enteric pathogen, but it has not changed the morbidity caused by such infections. This Review focuses on the interactions between enteric pathogens and human genetic determinants that alter intestinal function and inflammation and profoundly impair human health and development. We also discuss specific implications for novel approaches to interventions that are now opened by our rapidly growing molecular understanding.
\end{abstract}

\section{Introduction}

Infection of the intestinal tract with an increasingly recognized array of bacterial, parasitic, and viral pathogens can profoundly disrupt intestinal function with or without causing overt dehydrating diarrhea. Diarrhea is a syndrome that is frequently not differentiated clinically by specific etiologic agent. The use of glucose-electrolyte oral rehydration therapy (ORT) has dramatically reduced acute mortality from dehydration caused by diarrhea: estimates of global mortality from diarrhea declined from approximately 4.6 million annual deaths during the mid-1980s to the current estimate of 1.6-2.1 million $(1,2)$. Most of these deaths occur in children under the age of 5 years and occur in developing countries (Figure 1). In contrast to the decline in rates of mortality from diarrhea, rates of morbidity as a result of this syndrome remain as high as ever (1). In addition, we believe that morbidity arising from the malnutrition caused by persistent diarrhea and enteropathy resulting from chronic and recurring enteric infections is often not counted in estimates of the burden of diarrhea.

The absorptive function of a healthy intestinal tract is especially critical in the first few formative years of life. This is because, unlike many other species, the predominant brain and synapse development in humans occurs in the first 2 years after birth. Hence, the absorption of key nutrients during this time is critical to assure the optimal growth and development of the body, brain, and neuronal synapses that determine human capacity. Although a developing fetus and a breastfed child rob even a malnourished mother for their sustenance, upon leaving the womb or upon weaning, respec-

Nonstandard abbreviations used: CHERG, Child Health Epidemiology Research Group; CT, cholera toxin; EAEC, enteroaggregative E. coli; EPEC, enteropathogenic E. coli; ETEC, enterotoxigenic E. coli; HO-ORS, hypo-osmolar ORS; IBD, inflammatory bowel disease; LT, heat labile toxin; M, microfold (cell); ORNT, oral rehydration and nutrition therapy; ORS, oral rehydration solution; ORT, glucose-electrolyte oral rehydration therapy; RS, resistant starch.

Conflict of interest: R.L. Guerrant licensed fecal lactoferrin testing to TechLab Inc. and is cofounder of AlGlutamine LLC. W.A. Petri Jr. licensed technology for testing for Entamoeba bistolytica to TechLab Inc. The right to manufacture live oral cholera vaccine CVD103-HgR, coinvented by M.M. Levine, was licensed to Berna Biotech, a Crucell Company. W.A. Petri Jr., M. Miller, and M.M. Levine receive research funding from the Bill and Melinda Gates Foundation. The remaining authors have declared that no conflict of interest exists.

Citation for this article: J. Clin. Invest. 118:1277-1290 (2008). doi:10.1172/JCI34005. tively, human infants become totally dependent upon and vulnerable to food and water that are often contaminated with an increasingly recognized array of enteric pathogens. Yet one in six people ( 1.1 billion individuals) have no source of safe water and four in ten ( 2.6 billion individuals) lack even pit latrines, numbers projected to reach 2.9 and 4.2 billion, respectively, by 2025 (3), which results in numerous enteric infections and in persisting, or even worsening, rates of morbidity from diarrhea (1). Recent studies suggest the potential disability-adjusted life year (DALY) impact of morbidity resulting from diarrhea might be even greater than the impact of the still-staggering mortality caused by this syndrome $(1,4)$. DALYs are used to account for years lost to disability (i.e., morbidity over a lifetime) as well as years of life lost (i.e., age-specific mortality). The morbidity impact of enteric pathogens is related to their ability to directly impair intestinal absorption as well as their ability to cause diarrhea, both of which impair nutritional status. Thus, repeated infection with enteric pathogens that affect nutrient absorption and cause diarrhea have a lasting impact on the growth and development of a child. Furthermore, although malnourished children tend to "catch up" if given a chance, those with frequent bouts of diarrhea as a result of repeated infection with enteric pathogens have this catch-up growth linearly ablated (Figure 2) (5).

Growth shortfalls of up to $8.2 \mathrm{~cm}$ by age 7 years have been attributed to early childhood diarrhea and enteric parasite burden (ref. 6 and W. Checkley, unpublished observations). However, long-lasting and profound effects on fitness, cognition, and schooling are also observed. Indeed, it has been calculated that repeated bouts of diarrhea in the first 2 years of life can lead to a loss of 10 IQ points and 12 months of schooling by age 9 years (7-9). Furthermore, infection with specific enteric pathogens such as enteroaggregative E. coli (EAEC) and Cryptosporidium spp. can affect growth even in the absence of overt diarrhea (10-13). The vicious cycle of repeated enteric infections leading to malnutrition and developmental shortfalls (ref. 14 and W. Checkley, unpublished observations), and malnutrition in turn increasing both the rate and the duration of diarrheal illness (15), must be interrupted at any and all points possible.

Recent findings in several areas have opened new opportunities to interrupt this vicious cycle. First, the recognition of the longterm impact of repeated enteric infections has greatly increased the 


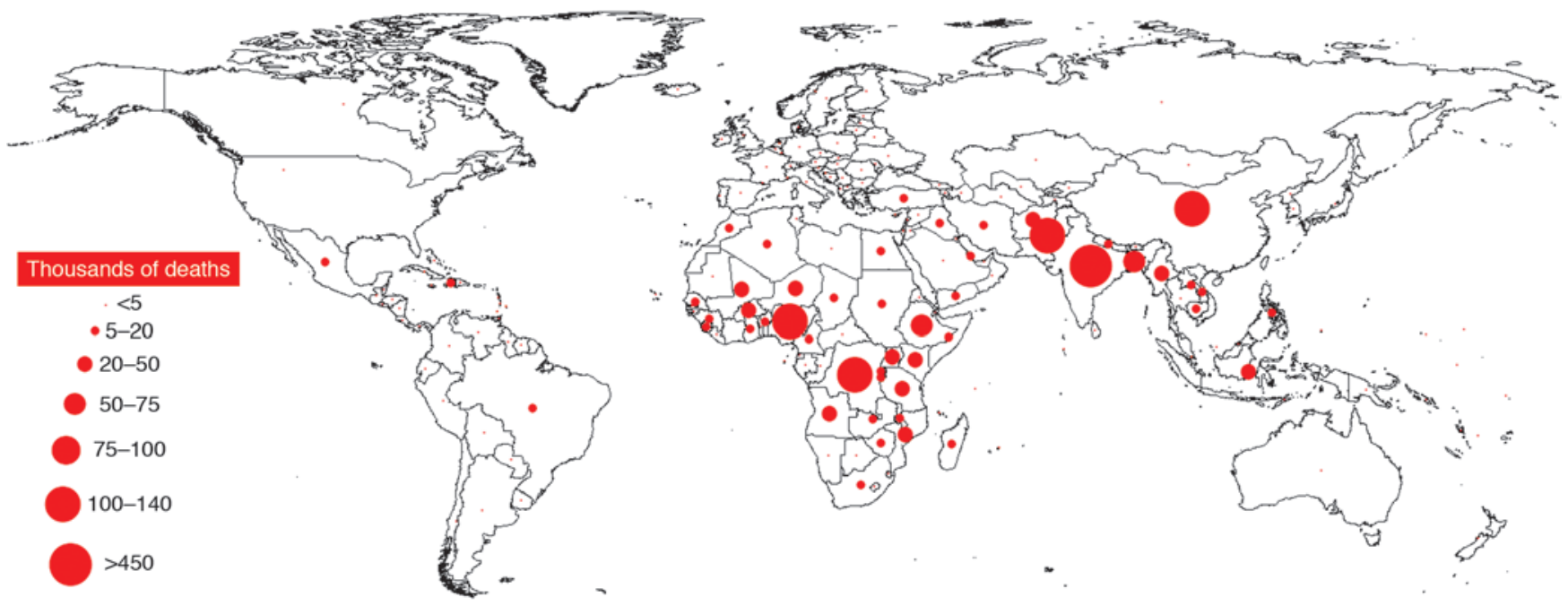

Figure 1

Worldwide distribution of deaths caused by diarrhea in children under 5 years of age in 2000. Although global mortality from diarrhea has declined in recent years, from approximately 4.6 million deaths during the mid-1980s to the current estimate of 1.6-2.1 million, most of these deaths occur in children in developing countries under the age of 5 years. Data are from the year 2000 (2).

estimated value of any effective intervention. Second, new molecular probes have increasingly revealed important viral, bacterial, and parasitic enteric pathogens and their virulence traits. Last, unraveling the host genome and even microbiome and using the information obtained to determine susceptibility to and outcomes from enteric infections has increasingly revealed potential avenues for novel interventions. For example, the APOE allele APOE4, which is associated with increased risk for cardiovascular and Alzheimer disease, was discovered to protect against the cognitive ravages of diarrhea (16). Because ApoE4 has been shown to drive an arginineselective transporter (17), these observations uncover a potential novel approach to repairing the damaged intestinal epithelium in individuals infected with enteric pathogens using arginine or its precursors, such as glutamine. It is therefore imperative that we understand the epidemiology, etiologies, and pathophysiology of

\section{Figure 2}

Repeated bouts of diarrhea linearly ablate "catch-up growth." The use of ORT has dramatically reduced acute mortality from dehydration caused by the diarrhea that often results from infection with an enteric pathogen. However, rates of morbidity as a result of enteric infections remain as high as ever. The morbidity impact of enteric pathogens is related to their ability to impair nutritional status, presumably by directly impairing intestinal absorption and by causing diarrhea. Therefore, repeated infection with enteric pathogens has a lasting impact on the growth and development of a child. Although malnourished children can catch up if given a chance, those with frequent bouts of diarrhea as a result of repeated infection with enteric pathogens have this catch-up growth linearly ablated. Weight-for-age $Z$ score $<-3$, children with a Z score more than 3 SD below mean weight-for-age value, considered severely malnourished; weight-for-age $Z$ score $>-3$, children with a $Z$ score less than 3 SD below mean weight-for-age value, considered not severely malnourished. Figure reproduced with permission from Lancet (5). enteric infections, as well as host-pathogen interactions, if we are to elucidate innovative interventions to control the still-devastating consequences of repeated malnourishing and disabling enteric infections in the most formative early years of childhood.

\section{Epidemiology and enteropathogens}

It is estimated that more than 10 million children younger than 5 years of age die each year worldwide, with only six countries accounting for half of these deaths (18). Pneumonia and diarrhea are the predominant causes, with malnutrition as an underlying cause in most cases. Although most mortality under 5 years of age occurs in India, Nigeria, and China, of the 20 countries with the highest mortality rates for individuals under 5 years of age, 19 are in Africa. The Child Health Epidemiology Research Group (CHERG), created by the WHO in 2001, has used various methods

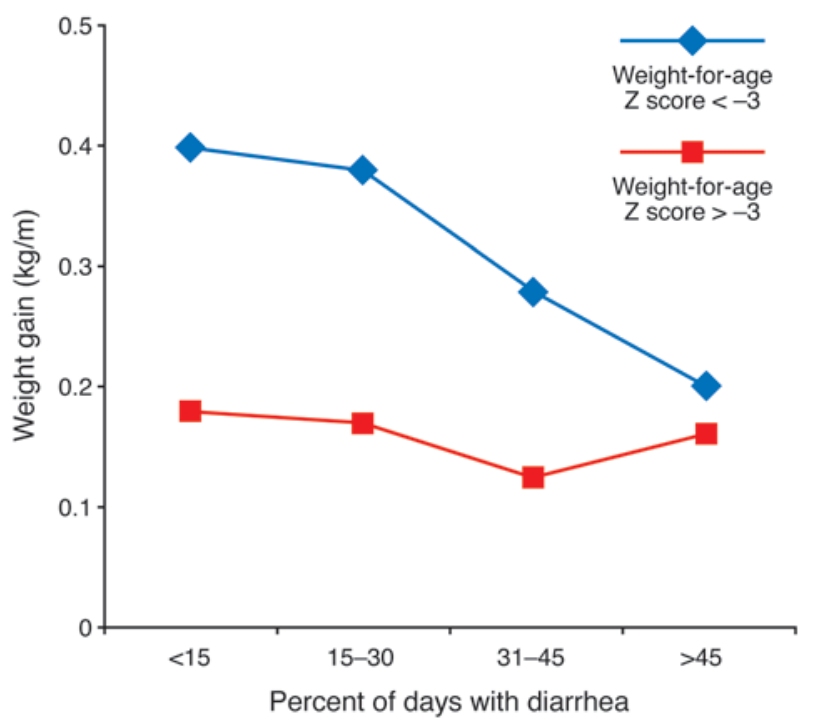


to determine specific causes of mortality (19). Based on older data, the CHERG estimated that the syndrome of diarrhea accounted for $18 \%$ of all deaths in children under the age of 5 , with malnutrition as a comorbid condition in $53 \%$ of all deaths.

A wide array of microbes cause diarrhea in children (20-24). The frequency of isolation of any one bacterium, parasite, or virus from children with diarrhea varies between developing and developed countries; within different geographic regions; among infants, children, and adults; between immunocompetent and immunocompromised individuals; between breastfed and nonbreastfed infants; among different seasons of the year; between rural and urban settings; and even over time in the same location and population. The extent to which exhaustive microbiologic techniques are applied to an epidemiologic study of diarrhea, and whether the study is community, clinic, or hospital based, also influence findings on the frequency of different enteric pathogens as the cause of diarrhea. Even in the best of studies no enteric pathogen is identified in one-third of cases, and infections with multiple putative enteric pathogens are observed frequently.

It is most important to ascertain the etiologic agents of diarrhea in children in developing countries, as this is the predominant group that dies from diarrhea and is subject to the vicious cycle of diarrhea and malnutrition (Figure 1). Enteric pathogens that are the cause of most severe acute diarrhea - as assessed by mortality - include rotavirus, Vibrio cholerae, Shigella spp., Salmonella spp., enteropathogenic E. coli (EPEC), and EAEC. Studies linking specific microbes with malnutrition are limited, but currently there are data linking malnutrition and attendant loss of cognitive function to infection with EAEC, enterotoxigenic E. coli (ETEC), Shigella spp., Ascaris lumbricoides, Cryptosporidium spp., Entamoeba histolytica, Giardia lamblia, and Trichuris trichiura (10-13, 25-30). Clearly, a better understanding of which enteric pathogens are responsible for how much of the burden of diarrhea morbidity and mortality is required. Although such elucidation would be challenging, it would permit a more informed allocation of resources for the development of treatments and vaccines and should be a research priority.

Determining the global incidence and prevalence of specific enteric pathogens is hardly a precise science; even less so are the ascertainment and attribution of the causes of diarrhea, malnutrition, disability, and deaths. All infants and children are colonized from birth with enteric organisms, which soon outnumber the number of cells in the host. Individuals are constantly challenged by pathogenic viruses, bacteria, and parasites. Although some viruses are geographically ubiquitous, such as rotavirus, which is estimated to infect $90 \%$ of the population of the world younger than 5 years of age, most enteric infections are environmentally determined, with restricted geographical and seasonal patterns related to the degree of sanitation and hygiene as well as access to clean drinking water. As sanitation, hygiene, and safe drinking water are directly related to economic development, over time this has effectively defined the incidence and prevalence of many of the bacterial agents of enteric infections. For example, cholera, shigellosis, and typhoid are most common in the most underserved populations, with greater incidence at times of limited water supply and flooding (during which water supplies can be contaminated by sewage).

The CHERG has also estimated morbidity from specific enteric pathogens based on extensive reviews of studies that have documented the etiologic agents of diarrhea in many community, outpatient, and inpatient settings (31). The most frequent etiologies of diarrhea at the community level were ETEC (14\%), EPEC (9\%), and G. lamblia (10\%); in outpatient settings, rotavirus (18\%), Campylobacter spp. (12.6\%), and EPEC (9\%) were most frequent; and in inpatient settings, rotavirus (25\%), EPEC (16\%), and ETEC (9\%) were most frequent (31). The CHERG findings also suggest that much more morbidity than mortality is caused by certain enteric pathogens, including G. lamblia, Cryptosporidium spp., E. histolytica, and Campylobacter spp. Conversely, enteric pathogens such as rotavirus, Salmonella spp., and V. cholerae 01 and 0139 seem to be important causes of mortality (31).

As the studies reviewed by the CHERG assessed the effects of one or more specific agents and were conducted over many years, many causes were not ascertained, and therefore the percentages listed above do not reflect the current distribution of the many diarrhea-causing pathogens. In addition, substantial secular changes have occurred in some of the previously highly endemic countries, such as India and the People's Republic of China, as well as some of the countries in Latin America. Recent reviews addressed the burden and data gaps caused by specific diarrhea-causing agents such as rotavirus (32), Shigella spp. (33), $V$. cholerae (34), ETEC, and Salmonella Typhi (35-37). Many populations, especially those located in rapidly developing areas in Latin America and Asia, have eliminated many specific diarrhea-causing agents through the process of development (38).

\section{Host susceptibility}

Individuals are not equally susceptible to infection by different microbes; if infected, possible outcomes range from asymptomatic colonization to death $(39,40)$. There are many reasons why individuals differ in their susceptibility to infection with enteric pathogens, including their genetic makeup and their ability to mount potent immune responses in the gut.

Genetics. The heritability of resistance to infection was demonstrated in a study of adopted children born before the advent of antibiotics (41). Premature death due to infection in the biologic parent increased the relative risk of death due to infection in the adopted child by 5.8-fold, a higher relative risk than that for parent and child both dying of vascular disease or cancer. In contrast, premature death of the adoptive parent due to infection carried no increased relative risk of death from infection for the child, demonstrating that a shared environment was not a major contributor to risk. Thus infectious diseases have as strong a genetic contribution to susceptibility as do vascular disease and cancer, if not stronger (41). Inherited resistance to infection has been supported by comparisons of monozygotic and dizygotic twins, where susceptibility to infectious diseases is most similar in genetically identical monozygotic twins $(39,40)$.

Exploration of the identity of the human genes that influence susceptibility to enteric infections is in its infancy, but the results are notable. The pioneering studies cited in Table $1(42-48)$ are enlightening as to the pathogenesis of intestinal infection and inflammation, factors that are crucial to determining how susceptible an individual is to infection with enteric pathogens. The evolutionary pressure of infectious diseases on the human genome has been substantial. Immune response genes in general, and the HLA locus specifically, are the most numerous and polymorphic of human genes. For example, the ability of specific HLA alleles of an individual to present microbial antigen to $\mathrm{T}$ cells might play a part in susceptibility to the enteric parasites E. histolytica and Cryptosporidium parvum (49-51). 


\section{Table 1}

Examples of genes implicated in susceptibility to enteric diseases

Infection or disease
Parasites
Ascaris lumbricoides
Cryptosporidium parvum/hominis
E. histolytica
Bacteria
C. difficile
EAEC
H. pylori
Salmonella spp.
V. cholerae 01
Viruses
Norovirus (Norwalk)
Syndromes
Traveler's diarrhea
IBD
Cognitive sequelae of diarrhea

\section{Gene(s) associated with susceptibility}

Chromosome $13 p$ at $113 \mathrm{cM}$, chromosome 11 at $43 \mathrm{cM}$, and chromosome 8 at $132 \mathrm{cM}$ (42); STAT6 (43); and ADRB2 (44) $\mathrm{DQB1}{ }^{*} 0301$ allele, DQB1 ${ }^{\star} 0301 / \mathrm{DRB} 1{ }^{*} 1101$ haplotype, and HLA class IB*15 (49) Colitis associated with DQB1*0601/DRB1*1501 haplotype (51); liver abscesses associated with HLA-DR3 (30)

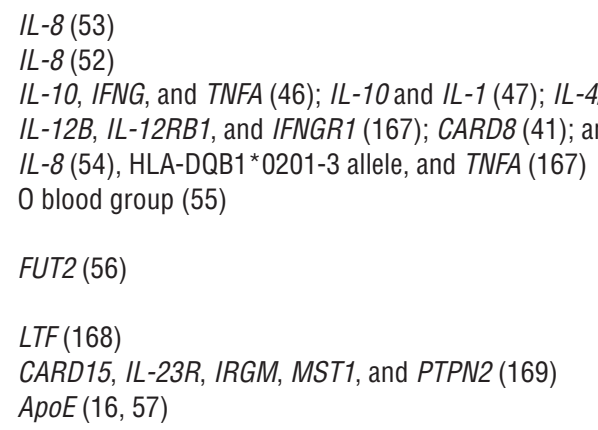

ADRB2, $\beta_{2}$ adrenergic receptor; FUT2, fucosyltransferase; IRGM, immunity-related GTPase; LTF, lactoferrin; MST1, macrophage stimulating 1; PTPN2, protein tyrosine phosphatase, nonreceptor type 2 .

In a second example, an exaggerated inflammatory response to a pathogen might contribute to disease $(52,53)$. Inflammation initiated by IL- 8 is central to the pathogenesis of several bacterial enteric pathogens, including Clostridium difficile, EAEC, and Helicobacter pylori. A SNP in the $I L-8$ gene 251 base pairs upstream of the start of transcription is associated with an increased amount of IL-8 produced in response to infection $(52,53)$. This polymorphism, in turn, has been found to be associated with an increased risk of diarrhea due to infection with C. difficile and EAEC as well as an increased risk of developing gastric cancer and gastric ulcers due to infection with H. pylori (52-54). The pathogenesis of these three bacterial diseases therefore might involve an exaggerated inflammatory response initiated by IL-8. One could envision antiinflammatory therapeutics directed at the IL-8 pathway as a potential therapy for these conditions based on the observations discussed here.

A third example is how the lack of host receptors for a microbe could explain susceptibility. Individuals with the O blood group are at increased risk of developing both cholera gravis following infection with $V$. cholerae and diarrhea following infection with Norwalk virus $(55,56)$. Norwalk virus is a norovirus that is the cause of winter vomiting disease and the most common cause of viral gastroenteritis. The virus binds to the $\mathrm{H}$ type- 1 oligosaccharide on gastric and duodenal epithelial cells that is synthesized, in part, by fucosyltransferase (an enzyme in the pathway of synthesis of A and B blood group antigens). Individuals homozygous for an inactivating mutation in fucosyltransferase were completely resistant to infection with Norwalk virus (56).

Finally, the damage to cognitive function that is associated with the vicious cycle of diarrhea and malnutrition also seems to be influenced by genetic polymorphisms $(16,57)$. There are several isoforms of the ApoE cholesterol transport protein, which is present in the serum, and the ApoE4 allele is associated with protection from the cognitive impairment associated with diarrhea and malnutrition in infancy as well as with increased risk of Alzheimer disease in later life
$(16,57)$. A unifying hypothesis is that ApoE4 functions to protect normal brain development amid heavy diarrhea burdens in early childhood through its cholesterol transport function (57).

The studies listed in Table 1 are mostly the results of a candidategene approach, where a preconceived hypothesis is used to identify a gene for study. For this reason, the results are limited by prior understanding or preexisting hypotheses about pathogenesis. A potentially more powerful genetic approach is a genome-wide association study, as this requires no a priori assumptions. In the future, the combination of both candidate-gene and genome-wide association studies, validated in different populations, promises to help explain host susceptibility to infection. With these answers will come new therapeutic and prophylactic approaches to the management of enteric infections and thereby diarrhea and its lasting impact on growth and development.

Gut immunity. Interspersed along the length of the human intestine, the largest immunologic organ of the body, is a myriad of lymphoid tissue aggregates overlain with microfold (M) cells, specialized epithelial cells that serve as antigen-sampling ports and inductive sites for immune responses (58). Depending on the route of immunization (mucosal versus parenteral) and the nature of the vaccine, various elicited effector immune responses can contribute to protection against infection with an enteric pathogen (59-61). If the titers of antigen-specific serum IgG following administration of a parenteral vaccine are sufficiently high, antibodies that transude onto the mucosal surface can interfere with invasive and noninvasive enteric pathogens (60). Live viral and bacterial vaccines (e.g., attenuated $S$. Typhi) stimulate an array of cell-mediated immune responses that are likely to be involved in protection $(62,63)$. However, the best-studied immune effector of the gut is the mucosal protease-resistant secretory IgA that appears following immunization or infection with enteropathogens such as rotavirus, $V$. cholerae, and E. histolytica $(64,65)$. The degree to which IgA-mediated B cell responses are induced is assessed by quantify- 
ing the amount of IgA in the stool or the number of IgA-secreting $\mathrm{B}$ cells in the circulation. IgA-secreting cells that make IgA specific to vaccine antigens are detected among peripheral blood mononuclear cells approximately 7-10 days after oral immunization (66-70). Those cells that express $\alpha_{4} \beta_{7}$ integrin homing receptors on their surface return to the intestinal tract, where they bind complementary mucosal addressin cell adhesion molecule-1 (MAdCAM1) molecules on endothelial cells of high endothelial venules (71-73). The induction of $\operatorname{IgA}$ in the intestine has been associated with immunity to diarrhea due to E. histolytica and rotavirus $(74,75)$.

\section{Pathophysiology}

Investigations into the pathophysiology of infectious diarrhea have elucidated fundamental processes of cell signaling and transport and established several mechanistic paradigms by which infectious agents interact with intestinal mucosa. Diarrhea caused by either infectious or noninfectious etiologies is invariably the result of changes in fluid and electrolyte transport in the small and/or large intestine (76). Although diarrhea represents increased fluid loss through the stool, intestinal fluid movement is secondary to solute movement, so that solute absorption and secretion are the driving forces for net fluid absorption and secretion, respectively. Thus, an understanding of diarrhea requires delineation of the regulation of ion transport in the epithelial cells of the small and large intestine. Net fluid secretion is secondary to stimulation of $\mathrm{Cl}^{-}$secretion in crypt cells and/or inhibition of electroneutral $\mathrm{NaCl}$ absorption in villous surface epithelial cells (Figure 3 and ref. 77).

An overall classification of the pathophysiology of infectious diarrhea is difficult because of the many different organisms associated with infectious diarrhea and the marked heterogeneity of their interactions with intestinal epithelial cells. At the extremes are enterotoxin-mediated intestinal secretion of fluids and electrolytes (e.g., cholera toxin [CT]; refs. 78, 79) and invasion of small or large intestinal enterocytes by the enteropathogen (e.g., Salmonella spp. and Shigella spp.), which results in extensive inflammatory changes leading to the production and release of one or more cytokines that affect intestinal epithelial function (80). In between are several paradigms that occur despite the enteropathogen lacking major enterotoxins and the ability to mediate invasion. Some organisms (e.g., EPEC) induce major changes in epithelial cell function following their interaction with intestinal epithelial cells, others (e.g., rotavirus, Cryptosporidium spp., and EAEC) disrupt or inflame the mucosa and cause disease mainly by triggering the host to produce cytokines, and yet others (e.g., C. difficile and enterohemorrhagic $E$. coli) produce cytotoxins.

Initial studies examined the effect of enterotoxins on ion transport, and the diarrhea in individuals with cholera has been considered a prototype, because there are no histological changes in the intestine despite substantial rates of net fluid and electrolyte secretion (78). After binding the apical membrane $\mathrm{Gm} 1$ ganglioside receptor, CT irreversibly activates adenylate cyclase and increases mucosal cAMP levels $(79,81)$. CT and cAMP have identical effects on intestinal epithelial cells: they stimulate active $\mathrm{Cl}^{-}$secretion by activating or inserting $\mathrm{Cl}^{-}$channels into the apical membrane of crypt cells and inhibit electroneutral $\mathrm{NaCl}$ absorption by decreasing the activity of parallel apical membrane $\mathrm{Na} / \mathrm{H}$ and $\mathrm{Cl} / \mathrm{HCO}_{3}$ exchange in villous cells, but they do not alter apical membrane glucose-stimulated $\mathrm{Na}$ absorption (Figure 3). The latter represents the physiological basis of oral rehydration solution (ORS) in the treatment of acute diarrhea (see below). CT production occurs only after ingestion of $V$. cholerae and its attachment to intestinal epithelial cells. This is in contrast to the enterotoxin of Staphylococcus aureus, which is produced ex vivo and causes symptoms of food poisoning soon after its ingestion. E. coli and ETEC produce two different enterotoxins, heat labile (LT) and heat stable (STa), which are likely responsible for most cases of traveler's diarrhea. LT is very similar in structure and function to CT, activating adenylate cyclase. By contrast, STa activates guanylate cyclase, resulting in increased mucosal cyclic GMP, which has similar, but not identical, effects on ion transport as cAMP $(82,83)$.

$\mathrm{CT}$ stimulation of $\mathrm{Cl}^{-}$secretion is considerably more complicated than solely its interaction with intestinal epithelial cells because tetrodotoxin (TTX; an inhibitor of neurotransmission) blocks approximately $50 \%$ of CT-stimulated fluid secretion, indicating that CT interacts with the enteric nervous system (ENS) (84). Present concepts indicate that CT induces the ENS to release vasoactive intestinal peptide (VIP), which activates adenylate cyclase and increases mucosal cAMP in intestinal epithelial cells. Thus, the ENS, as well as several lamina propria cells including myofibroblasts, have been identified as critical in the interaction of toxins with intestinal epithelial cells and the production of intestinal secretion or, in other cases, inflammation (84-86). Even rotaviruses, which invade and damage intestinal villous cells, release a novel $\mathrm{Ca}^{2+}$-dependent enterotoxin, NSP4, which inhibits brush border disaccharidases and glucose-stimulated $\mathrm{Na}^{+}$absorption $(87,88)$.

In striking contrast to the interaction of CT with intestinal epithelial cells, Shigella spp. invade colonic epithelium, causing substantial inflammation and ulceration. The mechanism by which Shigella spp. enter the colonic mucosa is novel in that they selectively cross $\mathrm{M}$ cells and then the basolateral membrane of epithelial cells to activate the production of cytokines and chemokines that cause inflammation, apoptosis, and tight junction disruption (89, 90). The series of events associated with the entry of Shigella spp. into intestinal epithelial cells results in invasion, disruption, and inflammation and thus inflammatory, and often dysenteric (i.e., bloody), diarrhea $(89,90)$.

Diarrhea caused by EPEC and noroviruses is caused by a third type of pathophysiology $(91,92)$. Although there is heterogeneity in the mechanism behind this type of pathophysiology, in general there is an absence of frank invasion and enterotoxin production. EPEC has been very well studied, with evidence of inhibition of $\mathrm{Na}-\mathrm{H}$ exchange and $\mathrm{Cl}-\mathrm{OH} / \mathrm{HCO}_{3}$ exchange but no stimulation of $\mathrm{Cl}^{-}$secretion (93). These physiological changes are secondary to the action of proteins secreted into epithelial cells via the type III secretion system (TTSS) of EPEC. Less well studied is the mechanism of diarrhea induced by norovirus. Studies in duodenal biopsies of patients infected with norovirus revealed an absence of histologic damage but stimulation of active $\mathrm{Cl}^{-}$secretion and altered tight junction function, most probably secondary to reduced expression of occludin and claudin-4 (92).

\section{Molecular diagnostics and biomarkers of inflammation and barrier disruption}

Some tools exist to assist in the identification of the enteric pathogens fueling the vicious cycle of malnutrition and diarrheal illness and to identify those most at risk from infection with these pathogens, but more are needed. The development of PCR diagnostics for use with stool samples that identify specific genes associated with enteric pathogens ranging from viruses to protozoa is exploding $(21,94-99)$. PCR has expanded the ability of both researchers 
A

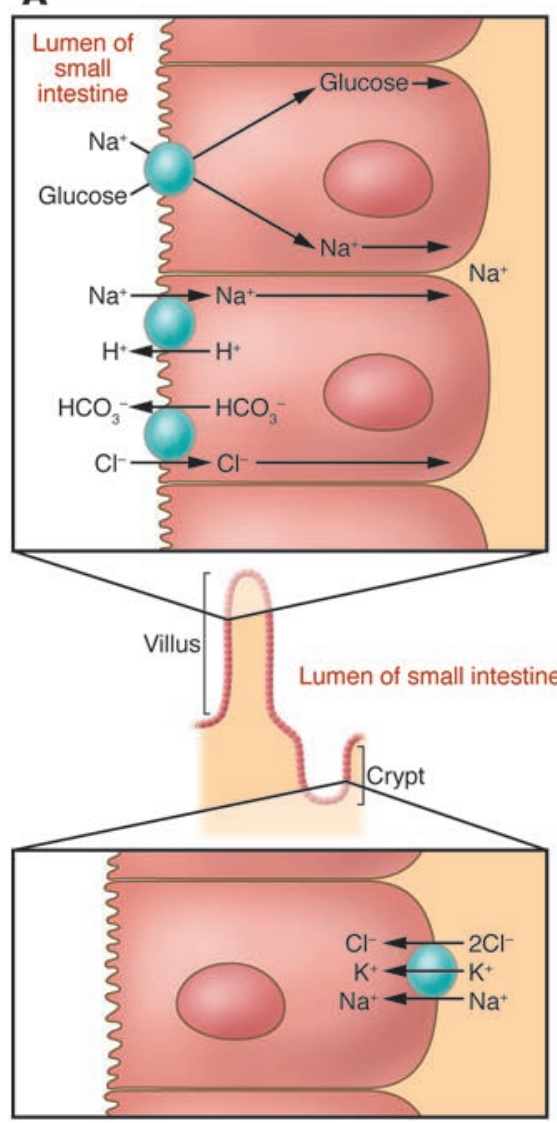

B

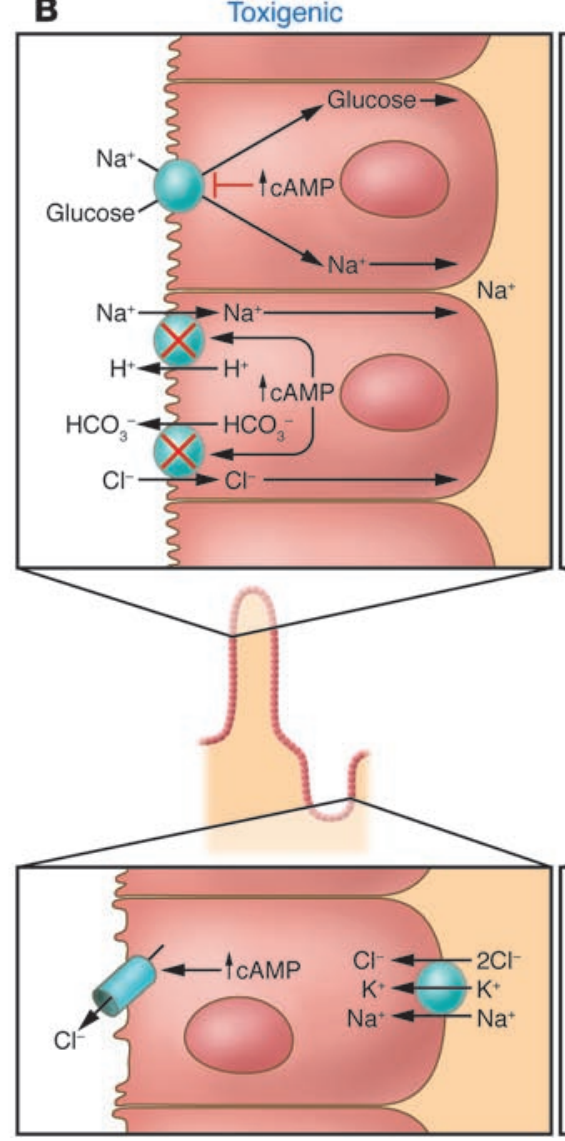

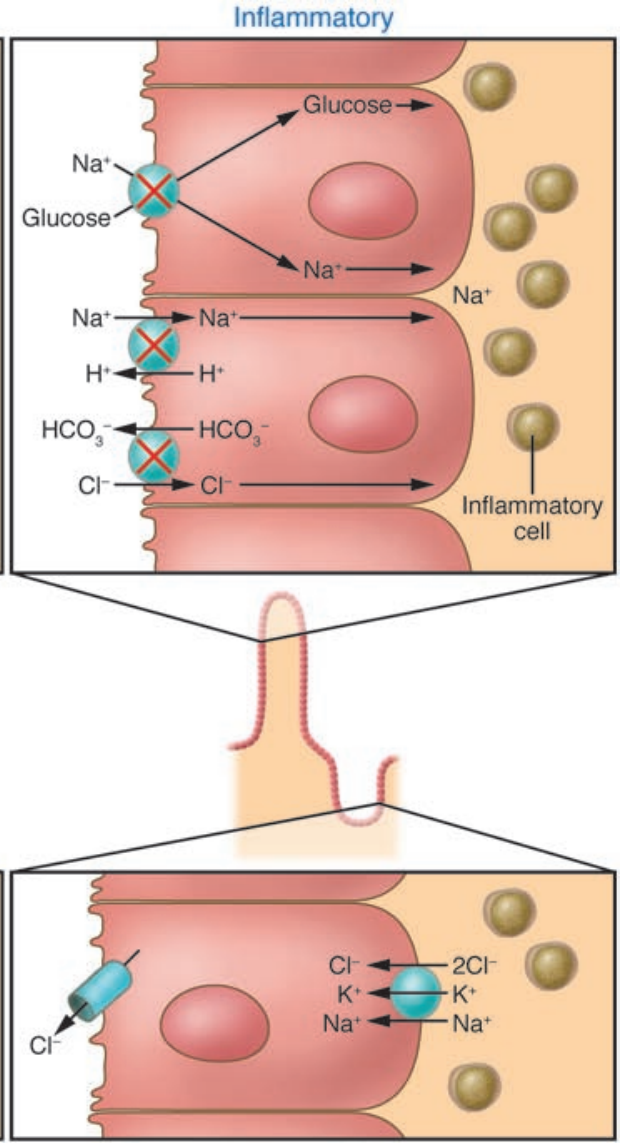

Figure 3

Movement of $\mathrm{Na}^{+}$and $\mathrm{Cl}^{-}$in the small intestine. (A) Movement in normal subjects. $\mathrm{Na}^{+}$is absorbed by two different mechanisms in absorptive cells from villi: glucose-stimulated absorption and electroneutral absorption (which represents the coupling of $\mathrm{Na} / \mathrm{H}$ and $\mathrm{Cl} / \mathrm{HCO} \mathrm{O}_{3}$ exchanges). (B) Movement during diarrhea caused by a toxin and inflammation. In toxigenic diarrhea (caused, for example, by the enterotoxin produced by $V$. cholerae), increased mucosal levels of cAMP inhibit electroneutral $\mathrm{NaCl}$ absorption but have no effect on glucose-stimulated $\mathrm{Na}^{+}$absorption. In inflammatory diarrhea (e.g., following infection with Shigella spp. or Salmonella spp.) there is extensive histological damage, resulting in altered cell morphology and reduced glucose-stimulated $\mathrm{Na}^{+}$and electroneutral $\mathrm{NaCl}$ absorption. The role of one or more cytokines in this inflammatory response is critical. In secretory cells from crypts, $\mathrm{Cl}^{-}$secretion is minimal in normal subjects and is activated by cAMP in toxigenic and inflammatory diarrhea.

and clinicians to identify the presence of previously unsuspected pathogens, a discovery that has a substantial impact on the understanding of enteric pathogen epidemiology as well as the management of disease. For example, Nataro et al. recently identified EAEC as the most common bacterial cause of diarrhea in two cities in the United States, a finding previously unsuspected due to the difficulty of identifying EAEC by tissue culture (100).

The response of an individual to an enteric infection can determine the severity of the disease and its long-term consequences as much as, or more than, the pathogen itself. Therefore, qualitative and quantitative measures of intestinal inflammation are necessary to determine its importance and to direct and evaluate potential novel interventions. One important marker of intestinal inflammation is fecal lactoferrin, an iron-binding glycoprotein that protects against infection with Gram-negative bacteria by sequestering iron and by disrupting the outer membrane of the bacteria (101). Both qualitative and quantitative assays for lactoferrin are available. Evaluating for elevated levels of lactoferrin in the stool of patients with suspected infectious diarrhea or known inflammatory bowel disease (IBD) can not only inform treatment decisions by signaling whether the symptoms are the result of an inflammatory bacterial infection or an IBD flare, but also provide an indication of whether a patient has responded to treatment to eradicate an infection (102-105). Fecal calprotectin, a cytoplasmic protein released by activated polymorphonuclear cells and possibly by macrophages, has also been proposed as a useful marker for intestinal inflammation, particularly in individuals with IBD. However, its use in the diagnosis of intestinal infection has not been investigated to the same degree as fecal lactoferrin (106-108).

Measures of intestinal permeability provide another important metric of the impact of an enteric infection. Calculation of the lactulose/mannitol ratio provides insight into both the integrity of the epithelium of the small intestine and its absorptive surface area. Lactulose is a disaccharide that is not absorbed by healthy enterocytes. Substantial absorption (and hence urinary excretion) indicates damage to the integrity of the intestinal epithelium. Mannitol is a monosaccharide that is absorbed passively, and the level of its absorption (and urinary excretion) provides an estimate 
of the functional absorptive surface area (109). Another sugar that can be used to evaluate absorptive surface area is D-xylose; in contrast to the lactulose/mannitol ratio, blood and urine samples can be analyzed (110). Demonstration of enteropathy by serial measurements of lactulose/mannitol ratios in Gambian children has shown that up to $43 \%$ of growth faltering can be explained by chronic damage to the intestinal epithelium, probably induced by recurrent enteric infection (111).

\section{Enteric vaccines}

There are two main approaches to primary prevention of enteric infections: (a) improved water and sanitation and (b) vaccination. Because most acute diarrhea is associated with fecal-oral transmission, improved sanitation and water quality are critical to decreasing the transmission of enteric pathogens. In a broad sense, better sanitation is meant to include improved personal hygiene practices as well as community sanitation.

Vaccine development is a lengthy and expensive process, ordinarily taking $8-15$ years and hundreds of millions of dollars to bring a vaccine candidate from concept to licensed product so that it can become a public health tool. Multiple factors influence what enteric vaccines get developed and how extensively they are used after licensing, such as disease burden and geographic distribution; epidemiologic behavior of the pathogen (epidemic versus endemic); scientific feasibility (e.g., single serotype versus multiple serotypes and existence of a correlate of protection); public perception; and the estimated market for the vaccine. At the present time only vaccines against infection with rotavirus, $V$. cholerae $\mathrm{O} 1$, and $S$. Typhi are commercially available (Table 2).

Vaccines against agents that cause mortality, severe disease, and epidemics. WHO committees have given the highest priority to the development of new or improved vaccines against rotavirus, Shigella spp., ETEC, V. cholerae O1, and S. Typhi, because these enteric pathogens contribute most to pediatric mortality and severe morbidity in developing countries as well as to epidemic disease. Between 1980 and 1999, new vaccines against infection with rotavirus, $V$. cholerae O1, and S. Typhi were licensed (Table 2). In contrast, there have been no vaccines yet licensed specifically to prevent diarrheal illness caused by Shigella spp. or ETEC. Although the new typhoid and cholera vaccines have been popular among travelers from industrialized countries who visit less-developed countries, use of these vaccines to control endemic and epidemic typhoid and cholera in developing countries has been limited. However, the use of oral cholera vaccines to control epidemic disease has met with good results $(112,113)$. The failure to use these vaccines more extensively in developing countries sends a signal of market failure that has impeded support for the development of vaccines against ETEC and other enteric pathogens.

Postlicensure surveillance incriminated the first licensed rotavirus vaccine, a tetravalent rhesus reassortant rotavirus vaccine (Rotashield; Wyeth), as being associated with intussusception, an uncommon but serious adverse reaction, among infants in the United States (114); eventually use of this vaccine was discontinued. Two newly licensed rotavirus vaccines, RotaTeq (Merck) and Rotarix (GSK), are filling the need for prevention of rotavirus-induced gastroenteritis in infants in industrialized and transitional countries $(115,116)$. Enormous prelicensure safety trials (involving approximately 60,000-70,000 infants) and postlicensure surveillance have indicated that these vaccines do not trigger intussusception with the frequency observed with Rotashield.
Randomized controlled field trials with these new vaccines are assessing their efficacy and practicality in preventing severe rotavirus-induced gastroenteritis in infants in developing countries in Africa and Asia.

A second generation of vaccines to prevent infection with $V$. cholerae $\mathrm{O} 1$ and $S$. Typhi is under development (Table 3; refs. 117-124). New typhoid vaccines include a Vi conjugate vaccine, for which a phase 3 clinical trial has been completed, and recombinant singledose live oral vaccines, which are currently in phase 2 clinical trials. Two new live cholera vaccines are in phase 2 clinical trials.

Vaccines to prevent infection with Shigella spp. and ETEC are also under development (Table 4; refs. 125-137). Two approaches to develop vaccines to prevent infection with Shigella spp. have demonstrated efficacy in field trials (128). The first approach is the development of conjugate vaccines in which Shigella $\mathrm{O}$ polysaccharides are covalently linked to carrier proteins $(128,129)$. The second approach is the development of live oral vaccines based on attenuated derivatives of wild-type Shigella spp. that are well tolerated and retain immunogenicity (125-128). Only one ETEC vaccine candidate, an oral mix of inactivated fimbriated ETEC in combination with the B subunit of CT, has reached phase 3 efficacy trials among children in developing countries, and it did not demonstrate statistically significant protection (134). Other vaccines designed to protect against infection with ETEC that are in clinical trials, or for which clinical trials are imminent, are listed in Table 4.

Other enteric pathogens and vaccine development. Other enteric pathogens that are not major causes of mortality and do not typically cause epidemics are nevertheless the focus of vaccine development because they cause a high incidence of endemic milder or persistent diarrhea or result in nutritional and cognitive development deficits. Vaccines are being developed to protect against infection with the diarrhea-causing enteric pathogens noroviruses (138), Campylobacter jejuni (139), C. difficile (140), EPEC (141), E. histolytica (142), Cryptosporidium spp. $(143,144)$, and EAEC as well as the enteric fever-causing pathogens Salmonella Paratyphi A and Salmonella Paratyphi B (145).

Biotechnology and enteric vaccines. Virtually every modern biotechnological approach has been applied in enteric vaccine development, with many candidates reaching clinical trials. Examples of oral vaccine strategies include transgenic plants as edible vaccines, viruslike particles (VLPs), recombinant attenuated bacteria, bacterial live vector vaccines, reassortant virus vaccines, polylactide-polyglycolide microsphere antigen delivery systems, and antigen coadministered with mucosal adjuvant. Parenteral vaccination strategies include polysaccharide-protein conjugate vaccines, synthetic oligosaccharides, and transcutaneous immunization using skin patches impregnated with purified ETEC fimbriae and LT. Two areas that could revolutionize enteric vaccine research are the development of new well-tolerated mucosal adjuvants that manipulate the innate immune system to enhance the adaptive immune response to oral vaccines and the use of lectins or other means to target vaccine antigens or delivery vehicles directly to intestinal $\mathrm{M}$ cells.

\section{Scientific challenges that remain}

Novel diagnostics and impact assessment. The greatest scientific challenges that remain if the impact of enteric infections on morbidity and mortality are to be substantially reduced are to measure and stem the huge human and societal costs of enteric infections. Better data showing the costly developmental and microbial impact of enteric infections (in terms of DALYs) can help advocate for the 


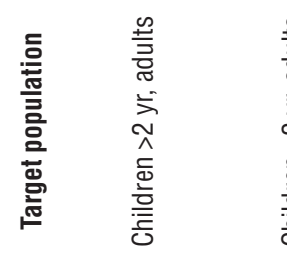

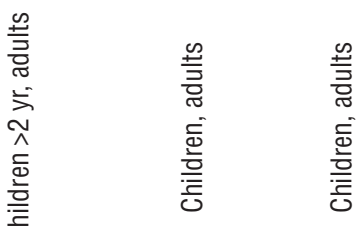

壳

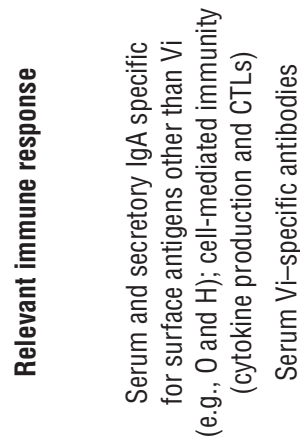
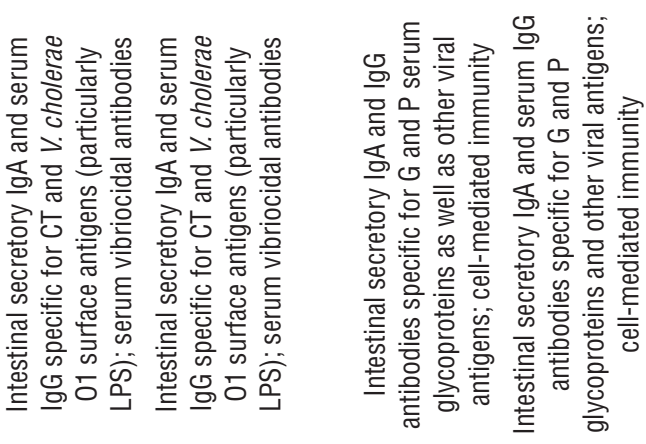

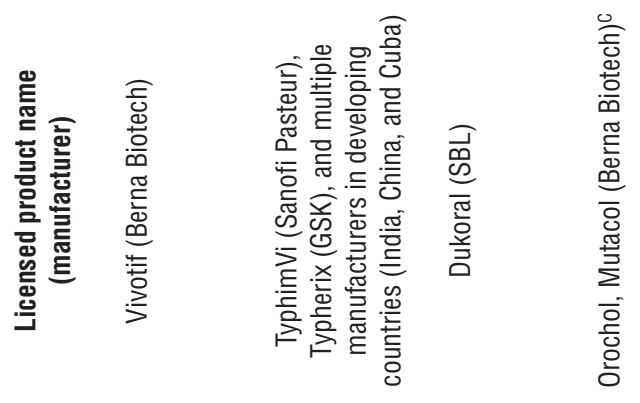
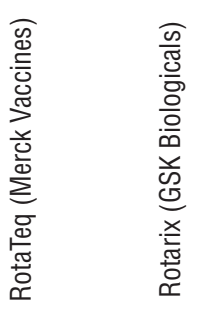

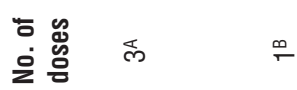

$\sim$

$m$

$\sim$

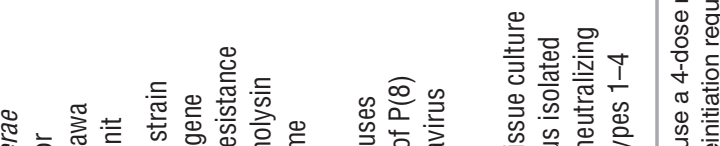

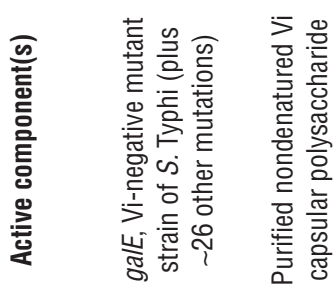

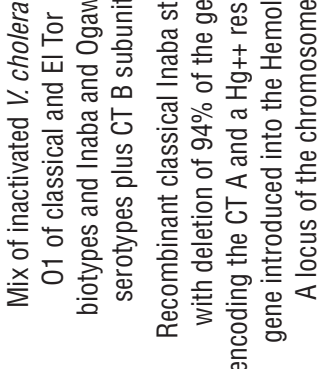

궁

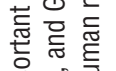
品 它

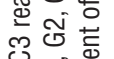

गु

产产圧

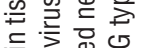

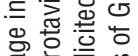
㐘

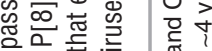

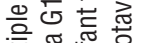

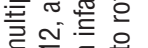

$\overline{\frac{\pi}{5}} \quad \overline{\frac{\pi}{0}}$

$\overline{\frac{\pi}{5}}$

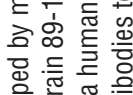

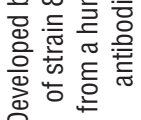<smiles>C1CCCCC2CCCC2CCC1</smiles>

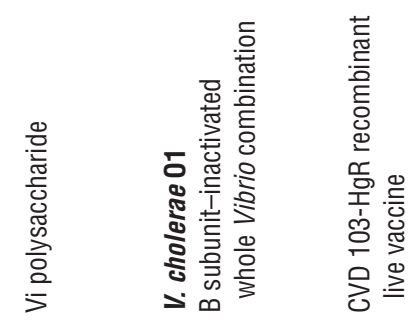

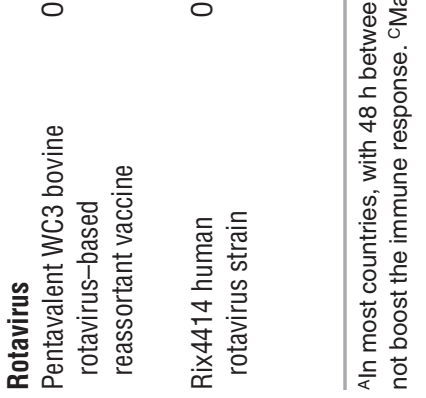

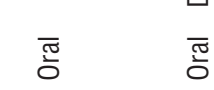
\% 
Table 3

New generation unlicensed vaccines against typhoid and cholera

\begin{tabular}{|c|c|c|c|c|c|c|}
\hline Vaccine & $\begin{array}{l}\text { Immunization } \\
\text { route }\end{array}$ & $\begin{array}{l}\text { No. of } \\
\text { doses }\end{array}$ & Developer & Status & Relevant immune response(s) & Ref. \\
\hline \multicolumn{7}{|l|}{ S. Typhi } \\
\hline Vi conjugate & Parenteral & 2 & $\begin{array}{l}\text { National Institute } \\
\text { of Child Health and } \\
\text { Human Development }\end{array}$ & Phase $3^{A}$ & Serum IgG specific for Vi & $(117,118)$ \\
\hline $\begin{array}{l}\text { Attenuated } S \text {. Typhi } \\
\text { strain M01ZH09 }\end{array}$ & Oral & 1 & Emergent Biosolutions & Phase 2 & $\begin{array}{l}\text { Serum and secretory IgA specific for } \\
\text { surface antigens other than } \mathrm{Vi} \text { (e.g., } \mathrm{O} \text { and } \mathrm{H})\end{array}$ & (119) \\
\hline $\begin{array}{l}\text { Attenuated S. Typhi } \\
\text { strain CVD 908-htrA }\end{array}$ & Oral & 1 & $\begin{array}{l}\text { Center for Vaccine } \\
\text { Development, } \\
\text { University of Maryland }\end{array}$ & Phase 2 & $\begin{array}{l}\text { Serum and secretory IgA specific for } \\
\text { surface antigens other than Vi (e.g., } 0 \text { and H); } \\
\text { cell-mediated immunity (cytokine } \\
\text { production and CTLs) }\end{array}$ & $(120)$ \\
\hline $\begin{array}{l}\text { Attenuated S. Typhi } \\
\text { strain CVD } 909\end{array}$ & Oral & 1 & $\begin{array}{l}\text { Center for Vaccine } \\
\text { Development, } \\
\text { University of Maryland }\end{array}$ & Phase 2 & $\begin{array}{l}\text { Serum antibodies specific for surface } \\
\text { antigens other than } \mathrm{Vi} \text { (e.g., } \mathrm{O} \text { and } \mathrm{H} \text {; } \\
\text { secretory IgA responses toward Vi; } \\
\text { cell-mediated immunity (cytokine } \\
\text { production and CTLs) }\end{array}$ & $(121)$ \\
\hline $\begin{array}{l}\text { Attenuated } S \text {. Typhi } \\
\text { strain Ty800 }\end{array}$ & Oral & 1 & $\begin{array}{l}\text { Massachusetts General } \\
\text { Hospital and } \\
\text { Avant Immunotherapeutics }\end{array}$ & Phase 2 & $\begin{array}{l}\text { Serum and secretory IgA specific for } \\
\text { surface antigens other than Vi (e.g., } 0 \text { and } H \text { ) }\end{array}$ & $(122)$ \\
\hline \multicolumn{7}{|l|}{ V. cholerae 01} \\
\hline $\begin{array}{l}\text { Peru } 15 \text { recombinant } \\
\text { live vaccine }\end{array}$ & Oral & 1 & Avant Immunotherapeutics & Phase 2 & $\begin{array}{l}\text { Intestinal secretory IgA and serum IgG } \\
\text { specific for LPS and other surface } \\
\text { antigens; serum vibriocidal antibodies }\end{array}$ & (123) \\
\hline $\begin{array}{l}\text { El Tor Ogawa } \\
\text { Strain } 631\end{array}$ & Oral & 1 & Finlay Institute, Cuba & Phase 2 & $\begin{array}{l}\text { Intestinal secretory } \lg A \text { and serum } \lg G \\
\text { specific for LPS and other surface } \\
\text { antigens; serum vibriocidal antibodies }\end{array}$ & $(124)$ \\
\hline
\end{tabular}

ACompleted, with $89 \%$ efficacy over 46 months' follow-up.

sanitary revolution and improved antimicrobial effectiveness in underserved areas, better vaccine prevention, and improved oral rehydration and nutrition therapy (ORNT). For example, a simple, quick means to detect human fecal contamination of water could help assess and drive a sanitary revolution in areas of greatest need. Improved assessment of etiology-specific functional derangement and physical and cognitive impact could lead to therapies that target pathogens, inflammation, and/or injury repair.

Generic obstacles to developing vaccines against enteric pathogens. The existing licensed enteric vaccines defend against pathogens that have a single predominant serotype (e.g., those that cause typhoid or cholera) or just a few relevant antigenic types (rotavirus). In contrast, future vaccines to protect against infection with Shigella spp. and ETEC must confer broad protection against many serotypes or antigenic types. For example, a global vaccine to protect against infection with Shigella spp. will have to protect against 16 serotypes (of 50) that have high epidemiologic importance. These include Shigella dysenteriae 1 (the agent of epidemic Shiga dysentery), all 14 Shigella flexneri serotypes and subtypes (the main agents of shigellosis in developing countries; ref. 33), and Shigella sonnei (the common cause of shigellosis in transitional countries and travelers). One approach to achieve broad protection is based on a pentavalent mix of five serotypes: S. dysenteriae 1, S. sonnei, S. flexneri 2a, S. flexneri 3a, and $S$. flexneri 6 . Collectively, these S. flexneri serotypes share type- or group-specific antigens with the other 11 S. flexneri serotypes (128). If successful in humans, the pentavalent strategy is also applicable to conjugate vaccines and inactivated oral vaccine strategies (128).
Analogous approaches to developing broadly protective ETEC vaccines aim to include the epidemiologically most important ETEC fimbrial colonization factor antigens together with an antigen to stimulate neutralizing LT antitoxin. One innovative approach to achieve a vaccine broadly protective against both $\mathrm{Shi}$ gella spp. and ETEC modifies the pentavalent attenuated vaccine to protect against infection with the Shigella spp. described above so that each Shigella serotype is engineered to express two ETEC fimbriae or the B subunit of LT (136).

Another strategy that could confer broad protection against infection with either Shigella spp. or ETEC is based on eliciting protective immune responses to common protein antigens. For example, Shigella spp. have an invasiveness plasmid that encodes virulence proteins (e.g., IpaA-D and VirG) common to all pathogenic strains of Shigella. These proteins stimulate weak immune responses following natural disease. The challenge is to develop a vaccine that renders these antigens highly immunogenic and protective in a way they are not in nature. The burgeoning knowledge of new adjuvants based on stimulating the innate immune system (e.g., using TLR agonists) offers promise that this might be achievable.

Various oral polio, rotavirus, and cholera vaccines and one candidate Shigella vaccine have been less immunogenic when given to persons living in disadvantaged conditions in developing countries than when given to subjects in industrialized countries. The basis for this barrier must be elucidated in order to design ways to overcome it. Clues include the effects of bacterial overgrowth in the small intestine, malnutrition, and helminthic infection. 
Table 4

New generation unlicensed vaccines against Shigella spp. and ETEC

\begin{tabular}{|c|c|c|c|c|c|c|}
\hline Vaccine & $\begin{array}{l}\text { mmunization } \\
\text { route }\end{array}$ & $\begin{array}{l}\text { No. of } \\
\text { doses }\end{array}$ & Developer & Status & Relevant immune response(s) & Ref. \\
\hline \multicolumn{7}{|l|}{ Shigella spp. } \\
\hline $\begin{array}{l}\text { Attenuated S. sonnei } \\
\text { strain WRSS1 }\end{array}$ & Oral & 2 & $\begin{array}{l}\text { Walter Reed Army } \\
\text { Institute of Research }\end{array}$ & Phase 2 & $\begin{array}{l}\text { Intestinal secretory } \lg A \text { and serum IgG specific } \\
\text { for } 0 \text { antigen and virulence plasmid proteins }\end{array}$ & $(125)$ \\
\hline $\begin{array}{l}\text { Attenuated S. flexneri 2a } \\
\text { strain CVD 1208S }\end{array}$ & Oral & 2 & $\begin{array}{l}\text { Center for Vaccine } \\
\text { Development, } \\
\text { University of Maryland }\end{array}$ & Phase 1 & $\begin{array}{l}\text { Intestinal secretory } \lg A \text { and serum } \lg G \text { specific } \\
\text { for } 0 \text { antigen and virulence plasmid proteins }\end{array}$ & (126) \\
\hline $\begin{array}{l}\text { Attenuated S. flexneri 2a } \\
\text { strain SC602 }\end{array}$ & Oral & $1-2$ & Pasteur Institute & Phase 2 & $\begin{array}{l}\text { Intestinal secretory IgA and serum IgG specific } \\
\text { for } 0 \text { antigen and virulence plasmid proteins }\end{array}$ & $(127)$ \\
\hline $\begin{array}{l}\text { Attenuated S. dysenteriae } 1 \\
\text { strain SC599 }\end{array}$ & Oral & 2 & Pasteur Institute & Phase 2 & $\begin{array}{l}\text { Intestinal secretory IgA and serum IgG specific } \\
\text { for } 0 \text { antigen and virulence plasmid proteins }\end{array}$ & (128) \\
\hline $\begin{array}{l}\text { Shigella glycoconjugates } \\
\text { (0 polysaccharide covalently } \\
\text { linked to carrier protein) }\end{array}$ & i.m. & 2 & $\begin{array}{l}\text { National Institute } \\
\text { of Child Health and } \\
\text { Human Development }\end{array}$ & Phase 3 & Serum IgG specific for 0 antigen & (129) \\
\hline $\begin{array}{l}\text { Shigella invasion } \\
\text { complex (Invaplex) }\end{array}$ & Nasal & 3 & $\begin{array}{l}\text { Walter Reed Army } \\
\text { Institute of Research }\end{array}$ & Phase 1 & $\begin{array}{l}\text { Intestinal secretory IgA and serum IgG specific } \\
\text { for } 0 \text { antigen and virulence plasmid proteins }\end{array}$ & $(130)$ \\
\hline $\begin{array}{l}\text { Proteosomes (outer } \\
\text { membrane protein vesicles } \\
\text { of Group B meningitidis) } \\
\text { to which } S \text {. sonnei or } \\
\text { S. flexneri 2a LPS is adsorbed }\end{array}$ & Nasal & 2 & ID Biomedical ${ }^{\mathrm{A}}$ & Phase 1 & $\begin{array}{l}\text { Intestinal secretory } \lg A \text { and serum IgG } \\
\text { specific for } 0 \text { antigen }\end{array}$ & (131) \\
\hline Inactivated S. sonnei & Oral & $3-5$ & Emergent Biosolutions & Phase 1 & $\begin{array}{l}\text { Intestinal secretory IgA and serum IgG } \\
\text { specific for } 0 \text { antigen }\end{array}$ & (132) \\
\hline $\begin{array}{l}\text { Ty21a expressing } \\
\text { Shigella } 0 \text { antigens } \\
\text { ETEC }\end{array}$ & Oral & 3 & Aridis & Preclinical & $\begin{array}{l}\text { Intestinal secretory } \lg A \text { and serum } \lg G \\
\text { specific for } 0 \text { antigen }\end{array}$ & (133) \\
\hline $\begin{array}{l}\text { B subunit-inactivated } \\
\text { whole fimbriated ETEC } \\
\text { combination }\end{array}$ & Oral & 2 & $\begin{array}{l}\text { University of Goteborg } \\
\text { and SBL }\end{array}$ & Phase 3 & $\begin{array}{l}\text { Intestinal secretory IgA and serum } \lg G \\
\text { antibody specific for fimbrial colonization } \\
\text { factors and B subunit }\end{array}$ & (134) \\
\hline $\begin{array}{l}\text { Attenuated fimbriated } \\
\text { nontoxigenic } E \text {. coli } \\
\text { (derived from ETEC) }\end{array}$ & Oral & 2 & $\begin{array}{l}\text { Cambridge } \\
\text { Biostability Ltd. }\end{array}$ & & $\begin{array}{l}\text { Intestinal secretory IgA and serum IgG } \\
\text { specific for fimbrial colonization factors }\end{array}$ & (135) \\
\hline $\begin{array}{l}\text { Attenuated Shigella strains } \\
\text { expressing ETEC fimbrial } \\
\text { colonization factors and } \\
\text { B subunit of LTh }\end{array}$ & Oral & 2 & $\begin{array}{l}\text { Center for Vaccine } \\
\text { Development, } \\
\text { University of Maryland }\end{array}$ & Phase 1 & $\begin{array}{l}\text { Intestinal secretory } \lg A \text { and serum } \lg G \\
\text { antibody specific for fimbrial } \\
\text { colonization factors and B subunit of LT }\end{array}$ & $(136)$ \\
\hline $\mathrm{LTh}^{\mathrm{B}}$ & ranscutaneous & 2 & Iomai Vaccines & Phase 2 & $\begin{array}{l}\text { Serum IgG specific for B subunit of } L T \\
\text { (and fimbriae, if present in the vaccine) }\end{array}$ & (137) \\
\hline
\end{tabular}

ANow GSK Biologicals. BAlone or in combination with purified fimbrial colonization factors or fimbrial tip adhesin proteins. LTh, LT from a human ETEC.

The general effect of administering multiple oral vaccines in combination is either that the immune response to each component is adequately immunogenic or that minimal modifications of the ratio of one antigen to another are necessary to achieve satisfactory immunogenicity to all components. Examples include live oral polio and rotavirus vaccines as well as live oral typhoid with cholera vaccines.

The logistical difficulties of routine infant immunization and of mass immunization campaigns in developing countries would be simplified if the vaccines did not have to be maintained in a cold chain to assure their immunogenicity and efficacy. Formulating vaccines with certain sugars such as trehalose leads to "glassification," rendering the vaccines markedly resistant to high and low temperatures.
Novel approaches to ORT and ORNT. The principles for the treatment of acute diarrhea center around rehydration. During the past three decades, since the introduction of an iso-osmolar ORS, often referred to as WHO-ORS, there has been a dramatic decrease in childhood morbidity and mortality from acute diarrhea because the ORS corrects dehydration and metabolic acidosis. Despite the effectiveness of ORS, it does not dramatically reduce stool output, and thus mothers doubt its effectiveness. As a result, there have been many attempts to develop "super" or "super-super" ORSs. Meal-based, rice-based ORSs that are hypo-osmolar are more effective than WHO-ORS (146). Subsequent studies established that the hypo-osmolarity was primarily responsible for the increased effectiveness of meal-based ORSs (147). In 2003, hypo-osmolar ORS (HO-ORS) was established by 
the WHO and the Indian government as the preferred ORS to better prevent hypernatremia.

Another approach to develop an improved ORS was based on using the absorptive capacity of the colon to increase overall fluid absorption and thus to reduce stool output. This approach capitalized on the observation that short-chain fatty acid (SCFA) stimulation of fluid and $\mathrm{Na}$ absorption in the colon is not inhibited by cAMP (148). SCFAs are the major anion in stool. They are not in the normal diet, but they are synthesized by colonic bacteria from nonabsorbed carbohydrate. Thus, the addition of resistant starch (RS; starch that is relatively resistant to amylase digestion) to ORS should result in increased production of SCFAs and has been shown to enhance the effectiveness of ORS in the treatment of both cholera in adults and noncholera diarrhea in children $(149,150)$. Subsequent studies established that RS in HO-ORS substantially decreases both stool output and the time to the first formed stool in adults with cholera (151). Studies are now required to establish whether treating children with acute diarrhea of different etiologies and in different locations in the world with RScontaining HO-ORS is more effective than HO-ORS alone before RS-containing HO-ORS can be implemented as the next gold standard for ORT in both children and adults with acute diarrhea.

It has also been shown that zinc, in conjunction with ORS, is effective in reducing acute diarrhea by $15 \%-25 \%$; however, its mechanism of action is uncertain $(152,153)$. Oral zinc can correct a common micronutrient deficiency in children with diarrhea (154). It has also been shown to block basolateral $\mathrm{K}^{+}$channels and thus inhibit cAMP-induced $\mathrm{Cl}^{-}$secretion (155). A drug that acts as a $\mathrm{Cl}^{-}$channel blocker could also help treat acute diarrhea. At the present time there are at least two drug development programs seeking to establish the efficacy of novel compounds that block the $\mathrm{Cl}^{-}$channel CFTR and $\mathrm{Cl}^{-}$secretion.

Other novel therapeutic approaches target the inflammatory disruption or restoration of the damaged epithelium and its critical barrier and absorptive functions. It is estimated that the absorptive surface area of the normal adult human small bowel approximates a doubles tennis court, or, counting the ultrastruc- tural brush border, even more $(156,157)$. Yet this tennis court is repaved by constant epithelial cell renewal every 3-4 days. Because the major nutrient for this rapidly renewing epithelium is glutamine, it is not surprising that this provisionally essential amino acid becomes rate limiting for epithelial repair in malnourished individuals. The discovery that glutamine and its stable derivative, alanyl glutamine, drive not only epithelial repair but also electrogenic sodium absorption (even in the presence of villus damage) provides an attractive approach to ORNT (158-161). Glutamine causes improvement that cannot be completely explained by enhanced fluid and $\mathrm{Na}$ absorption, and it seems to improve intestinal epithelial cell integrity and enhance tight junction function (162-164). An additional key amino acid for renewal of the intestinal epithelium is arginine, which is often deficient in malnourished patients. Indeed, it is an arginine-selective cationic amino acid transporter that is upregulated by the ApoE4 allele associated with protection from the cognitive effects of diarrhea and malnutrition $(16,17)$, and this observation could explain, at least in part, the protective effect of the allele (57). Arginine might also provide a novel epithelial repairing therapy, and it was well tolerated in premature neonatal human infants, in whom it reduced the incidence of necrotizing enterocolitis (165).

\section{Summary}

The cost of the vicious cycle of enteric infections and malnutrition and their potential lasting impact is so great that multiple approaches to interrupt it must be taken. Fortunately, the recognition of this long-term impact and new molecular genetic tools enable the development and evaluation of interventions that can now be seen as increasingly important to child development, controlling resistant infections, and human health.

Address correspondence to: Richard L. Guerrant, Center for Global Health, Division of Infectious Diseases and International Health, University of Virginia School of Medicine, MR4, 409 Lane Road, Room 3148, Charlottesville, Virginia 22908, USA. Phone: (434) 924-5242; Fax: (434) 982-0591; E-mail: guerrant@virginia.edu.
1. Kosek, M., Bern, C., and Guerrant, R.L. 2003. The global burden of diarrhoeal disease, as estimated from studies published between 1992 and 2000. Bull World Health Organ. 81:197-204.

2. Keusch, G.T., et al. 2006. Diarrheal diseases. In Disease control priorities in developing countries. D.T. Jamison, et al., editors. Oxford University Press. New York, New York, USA. 371-388.

3. Mara, D.D. 2003. Water, sanitation and hygiene for the health of developing nations. Public Health. 117:452-456.

4. Guerrant, R.L., Kosek, M., Lima, A.A., Lorntz, B., and Guyatt, H.L. 2002. Updating the DALYs for diarrhoeal disease. Trends Parasitol. 18:191-193.

5. Schorling, J.B., and Guerrant, R.L. 1990. Diarrhoea and catch-up growth. Lancet. 335:599-600.

6. Moore, S.R., et al. 2001. Early childhood diarrhoea and helminthiases associate with long-term linear growth faltering. Int. J. Epidemiol. 30:1457-1464.

7. Guerrant, D.I., et al. 1999. Association of early childhood diarrhea and cryptosporidiosis with impaired physical fitness and cognitive function four-seven years later in a poor urban community in northeast Brazil. Am. J. Trop. Med. Hyg. 61:707-713.

8. Lorntz, B., et al. 2006. Early childhood diarrhea predicts impaired school performance. Pediatr. Infect. Dis. J. 25:513-520.

9. Niehaus, M.D., et al. 2002. Early childhood diarrhea is associated with diminished cognitive function 4 to 7 years later in children in a northeast Brazilian shantytown. Am. J. Trop. Med. Hyg. 66:590-593.

10. Checkley, W., et al. 2004. Effect of water and sanitation on childhood health in a poor Peruvian periurban community. Lancet. 363:112-118.

11. Checkley, W., et al. 1997. Asymptomatic and symptomatic cryptosporidiosis: their acute effect on weight gain in Peruvian children. Am. J. Epidemiol. 145:156-163.

12. Checkley, W., et al. 1998. Effects of Cryptosporidium parvum infection in Peruvian children: growth faltering and subsequent catch-up growth. Am. J. Epidemiol. 148:497-506.

13. Steiner, T.S., Lima, A.A., Nataro, J.P., and Guerrant, R.L. 1998. Enteroaggregative Escherichia coli produce intestinal inflammation and growth impairment and cause interleukin-8 release from intestinal epithelial cells. J. Infect. Dis. 177:88-96.

14. Mata, L.J. 1978. The children of Santa Maria Cauque: a prospective field study of health and growth. MIT Press. Cambridge, Massachusetts, USA. 395 pp.

15. Guerrant, R.L., Schorling, J.B., McAuliffe, J.F., and de Souza, M.A. 1992. Diarrhea as a cause and an effect of malnutrition: diarrhea prevents catch-up growth and malnutrition increases diarrhea frequency and duration. Am. J. Trop. Med. Hyg. 47:28-35.

16. Oria, R.B., et al. 2005. APOE4 protects the cognitive development in children with heavy diarrhea burdens in Northeast Brazil. Pediatr. Res. 57:310-316.
17. Colton, C.A., et al. 2001. Apolipoprotein E acts to increase nitric oxide production in macrophages by stimulating arginine transport. Biochim. Biophys. Acta. 1535:134-144.

18. Black, R.E., Morris, S.S., and Bryce, J. 2003. Where and why are 10 million children dying every year? Lancet. 361:2226-2234.

19. Bryce, J., Boschi-Pinto, C., Shibuya, K., and Black, R.E. 2005. WHO estimates of the causes of death in children. Lancet. 365:1147-1152.

20. Cheng, A.C., McDonald, J.R., and Thielman, N.M. 2005. Infectious diarrhea in developed and developing countries. J. Clin. Gastroenterol. 39:757-773.

21. Brooks, J.T., et al. 2006. Surveillance for bacterial diarrhea and antimicrobial resistance in rural western Kenya, 1997-2003. Clin. Infect. Dis. 43:393-401.

22. Steiner, T.S., Samie, A., and Guerrant, R.L. 2006. Infectious diarrhea: new pathogens and new challenges in developed and developing areas. Clin. Infect. Dis. 43:408-410.

23. Haque, R., et al. 2003. Epidemiologic and clinical characteristics of acute diarrhea with emphasis on Entamoeba histolytica infections in preschool children in an urban slum of Dhaka, Bangladesh. Am. J. Trop. Med. Hyg. 69:398-405.

24. Clark, B., and McKendrick, M. 2004. A review of viral gastroenteritis. Curr. Opin. Infect. Dis. 17:461-469.

25. Mata, L. 1992. Diarrheal disease as a cause of malnutrition. Am. J. Trop. Med. Hyg. 47:16-27. 
26. Mondal, D., Petri, W.A., Jr., Sack, R.B., Kirkpatrick, B.D., and Haque, R. 2006. Entamoeba histolyticaassociated diarrheal illness is negatively associated with the growth of preschool children: evidence from a prospective study. Trans. R. Soc. Trop. Med. Hyg. 100:1032-1038.

27. Dale, D.C., and Mata, L.J. 1968. Studies of diarrheal disease in Central America. XI. Intestinal bacterial flora in malnourished children with shigellosis Am. J. Trop. Med. Hyg. 17:397-403.

28. Crompton, D.W. 1992. Ascariasis and childhood malnutrition. Trans. R. Soc. Trop. Med. Hyg. 86:577-579.

29. Berkman, D.S., Lescano, A.G., Gilman, R.H., Lopez, S.L., and Black, M.M. 2002. Effects of stunting, diarrhoeal disease, and parasitic infection during infancy on cognition in late childhood: a follow-up study. Lancet. 359:564-571.

30. Tarleton, J.L., et al. 2006. Cognitive effects of diarrhea, malnutrition, and Entamoeba histolytica infection on school age children in Dhaka, Bangladesh. Am. J. Trop. Med. Hyg. 74:475-481.

31. Lanata, C.F., Mendoza, W., and Black, R.E. 2007. Improving diarrhoea estimates. WHO. http://www. who.int/entity/child_adolescent_health/documents/pdfs/improving_diarrhoea_estimates.pdf.

32. Parashar, U.D., Bresee, J.S., Gentsch, J.R., and Glass, R.I. 1998. Rotavirus. Emerg. Infect. Dis. 4:561-570.

33. Kotloff, K.L., et al. 1999. Global burden of Shigella infections: implications for vaccine development and implementation of control strategies. Bull. World Health Organ. 77:651-666.

34. Griffith, D.C., Kelly-Hope, L.A., and Miller, M.A. 2006. Review of reported cholera outbreaks world wide, 1995-2005. Am. J. Trop. Med. Hyg. 75:973-977.

35. Crump, J.A., Ram, P.K., Gupta, S.K., Miller, M.A., and Mintz, E.D. 2007. Part I. Analysis of data gaps pertaining to Salmonella enterica serotype Typhi infections in low and medium human development index countries, 1984-2005. Epidemiol. Infect. doi:10.1017/S0950268807009338.

36. Gupta, S.K., et al. 2007. Part III. Analysis of data gaps pertaining to enterotoxigenic Escherichia coli infections in low and medium human development index countries, 1984-2005. Epidemiol. Infect. doi:10.1017/S095026880700934X.

37. Ram, P.K., Crump, J.A., Gupta, S.K., Miller, M.A., and Mintz, E.D. 2007. Part II. Analysis of data gaps pertaining to Shigella infections in low and medium human development index countries, 1984-2005. Epidemiol. Infect. doi:10.1017/ S0950268807009351.

38. Velazquez, F.R., et al. 2004. Diarrhea morbidity and mortality in Mexican children: impact of rotavirus disease. Pediatr. Infect. Dis. J. 23:S149-S155.

39. Burgner, D., Jamieson, S.E., and Blackwell, J.M. 2006. Genetic susceptibility to infectious diseases: big is beautiful, but will bigger be even better? Lan cet Infect. Dis. 6:653-663.

40. Hill, A.V. 2006. Aspects of genetic susceptibility to human infectious diseases. Annu. Rev. Genet. 40:469-486.

41. Sorensen, T.I., Nielsen, G.G., Andersen, P.K., and Teasdale, T.W. 1988. Genetic and environmental influences on premature death in adult adoptees. N. Engl. J. Med. 318:727-732

42. Williams-Blangero, S., et al. 2008. Localization of multiple quantitative trait loci influencing susceptibility to infection with Ascaris lumbricoides. J. Infect. Dis. 197:66-71.

43. Peisong, G., et al. 2004. An asthma-associated genetic variant of STAT6 predicts low burden of ascaris worm infestation. Genes Immun. 5:58-62.

44. Ramsay, C.E., et al. 1999. Polymorphisms in the beta2-adrenoreceptor gene are associated with decreased airway responsiveness. Clin. Exp. Allergy. 29:1195-1203.

45. Zambon, C.F., et al. 2005. Pro- and anti-inflammatory cytokines gene polymorphisms and Heli- cobacter pylori infection: interactions influence outcome. Cytokine. 29:141-152.

46. Sicinschi, L.A., et al. 2006. Gastric cancer risk in a Mexican population: role of Helicobacter pylori CagA positive infection and polymorphisms in interleukin-1 and -10 genes. Int. J. Cancer. 118:649-657.

47. Pessi, T., et al. 2005. Genetic and environmental factors in the immunopathogenesis of atopy: interaction of Helicobacter pylori infection and IL4 genetics. Int. Arch. Allergy Immunol. 137:282-288.

48. Thye, T., Burchard, G.D., Nilius, M., Muller-Myhsok, B., and Horstmann, R.D. 2003. Genomewide linkage analysis identifies polymorphism in the human interferon-gamma receptor affecting Helicobacter pylori infection. Am. J. Hum. Genet. 72:448-453.

49. Kirkpatrick, B.D., et al. 2008. Association between Cryptosporidium infection and human leukocyte antigen class I and class II alleles. J. Infect. Dis. 197:474-478

50. Duggal, P., et al. 2007. The study of associations between Entamoeba histolytica infection and disease with single nucleotide polymorphisms (SNPS) in immune response genes. In American Society of Tropical Medicine and Hygiene (ASTMH) 56th Annual Meeting. November 4-8. Philadelphia, Pennsylvania, USA. 82.

51. Duggal, P., et al. 2004. Influence of human leukocyte antigen class II alleles on susceptibility to Entamoeba histolytica infection in Bangladeshi children. J. Infect. Dis. 189:520-526.

52. Jiang, Z.D., et al. 2003. Genetic susceptibility to enteroaggregative Escherichia coli diarrhea: polymorphism in the interleukin-8 promotor region. J. Infect. Dis. 188:506-511.

53. Jiang, Z.D., et al. 2006. A common polymorphism in the interleukin 8 gene promoter is associated with Clostridium difficile diarrhea. Am. J. Gastroenterol. 101:1112-1116.

54. Garza-Gonzalez, E., et al. 2007. Assessment of the toll-like receptor 4 Asp299Gly, Thr399Ile and interleukin-8 -251 polymorphisms in the risk for the development of distal gastric cancer. $B M C$ Cancer. 7:70.

55. Glass, R.I., et al. 1985. Predisposition for cholera of individuals with O blood group. Possible evolutionary significance. Am. J. Epidemiol. 121:791-796.

56. Lindesmith, L., et al. 2003. Human susceptibility and resistance to Norwalk virus infection. Nat. Med. 9:548-553.

57. Oria, R.B., et al. 2007. Role of apolipoprotein E4 in protecting children against early childhood diarrhea outcomes and implications for later development. Med. Hypotheses. 68:1099-1107.

58. Corthesy, B. 2007. Roundtrip ticket for secretory IgA: role in mucosal homeostasis? J. Immunol. 178:27-32.

59. Neutra, M.R., and Kozlowski, P.A. 2006. Mucosal vaccines: the promise and the challenge. Nat. Rev. Immunol. 6:148-158.

60. Robbins, J.B., Chu, C., and Schneerson, R. 1992. Hypothesis for vaccine development: protective immunity to enteric diseases caused by nontyphoidal salmonellae and shigellae may be conferred by serum IgG antibodies to the O-specific polysaccharide of their lipopolysaccharides. Clin. Infect. Dis. 15:346-361.

61. Sztein, M.B. 2007. Cell-mediated immunity and antibody responses elicited by attenuated Salmonella enterica Serovar Typhi strains used as live oral vaccines in humans. Clin. Infect. Dis. 45(Suppl. 1):S15-S19.

62. Sztein, M.B., Tanner, M.K., Polotsky, Y., Orenstein, J.M., and Levine, M.M. 1995. Cytotoxic T lymphocytes after oral immunization with attenuated vaccine strains of Salmonella typhi in humans. J. Immunol. 155:3987-3993.

63. Salerno-Goncalves, R., Wahid, R., and Sztein, M.B.
2005. Immunization of volunteers with Salmonella enterica serovar Typhi strain Ty21a elicits the oligoclonal expansion of CD8+ T cells with predominant Vbeta repertoires. Infect. Immun. 73:3521-3530.

64. Holmgren, J., and Czerkinsky, C. 2005. Mucosal immunity and vaccines. Nat. Med. 11:S45-S53.

65. Losonsky, G.A., et al. 1988. Systemic and mucosal immune responses to rhesus rotavirus vaccine MMU 18006. Pediatr. Infect. Dis. J. 7:388-393.

66. Czerkinsky, C., Svennerholm, A.M., Quiding, M., Jonsson, R., and Holmgren, J. 1991. Antibody-producing cells in peripheral blood and salivary glands after oral cholera vaccination of humans. Infect. Immun. 59:996-1001.

67. Kantele, A. 1990. Antibody-secreting cells in the evaluation of the immunogenicity of an oral vaccine. Vaccine. 8:321-326.

68. Kantele, A., and Makela, P.H. 1991. Different profiles of the human immune response to primary and secondary immunization with an oral Salmonella typhi Ty21a vaccine. Vaccine. 9:423-427.

69. Losonsky, G.A., Tacket, C.O., Wasserman, S.S., Kaper, J.B., and Levine, M.M. 1993. Secondary Vibrio cholerae-specific cellular antibody responses following wild-type homologous challenge in people vaccinated with CVD $103-\mathrm{HgR}$ live oral cholera vaccine: changes with time and lack of correlation with protection. Infect. Immun. 61:729-733.

70. Losonsky, G.A., Kotloff, K.L., and Walker, R.I. 2003. $\mathrm{B}$ cell responses in gastric antrum and duodenum following oral inactivated Helicobacter pylori whole cell (HWC) vaccine and LT(R192G) in H pylori seronegative individuals. Vaccine. 21:562-565.

71. Kantele, A., et al. 2005. Unique characteristics of the intestinal immune system as an inductive site after antigen reencounter. J. Infect. Dis. 191:312-317.

72. Kunkel, E.J., and Butcher, E.C. 2003. Plasma-cell homing. Nat. Rev. Immunol. 3:822-829.

73. Brandtzaeg, P., and Johansen, F.E. 2005. Mucosal B cells: phenotypic characteristics, transcriptional regulation, and homing properties. Immunol. Rev. 206:32-63.

74. Haque, R., et al. 2006. Entamoeba histolytica infection in children and protection from subsequent amebiasis. Infect. Immun. 74:904-909.

75. Coulson, B.S., Grimwood, K., Hudson, I.L., Barnes, G.L., and Bishop, R.F. 1992. Role of coproantibody in clinical protection of children during reinfection with rotavirus. J. Clin. Microbiol. 30:1678-1684.

76. Fordtran, J.S. 1967. Speculations on the pathogenesis of diarrhea. Fed. Proc. 26:1405-1414.

77. Binder, H.J., and Sandle, G.I. 2007. Electrolyte transport in the mammalian colon. In Physiology of the gastrointestinal tract. L.R. Johnson, editor. Raven Press. New York, New York, USA. 2133-2172.

78. Field, M., Fromm, D., al-Awqati, Q., and Greenough, W.B., III. 1972. Effect of cholera enterotoxin on ion transport across isolated ileal mucosa. J. Clin. Invest. 51:796-804.

79. Guerrant, R.L., Chen, L.C., and Sharp, G.W. 1972. Intestinal adenyl-cyclase activity in canine cholera: correlation with fluid accumulation. J. Infect. Dis. 125:377-381.

80. Galan, J.E. 2001. Salmonella interactions with host cells: type III secretion at work. Annu. Rev. Cell Dev. Biol. 17:53-86.

81. Moss, J., and Vaughan, M. 1981. Mechanism of action of choleragen and E. coli heat-labile enterotoxin: activation of adenylate cyclase by ADP-ribosylation. Mol. Cell. Biochem. 37:75-90.

82. Mezoff, A.G., Giannella, R.A., Eade, M.N., and Cohen, M.B. 1992. Escherichia coli enterotoxin (STa) binds to receptors, stimulates guanyl cyclase, and impairs absorption in rat colon. Gastroenterology. 102:816-822.

83. Hughes, J.M., Murad, F., Chang, B., and Guerrant, R.L. 1978. Role of cyclic GMP in the action of heat-stable enterotoxin of Escherichia coli. Nature. 
271:755-756.

84. Cassuto, J., Jodal, M., Tuttle, R., and Lundgren, O. 1981. On the role of intramural nerves in the pathogenesis of cholera toxin-induced intestinal secretion. Scand. J. Gastroenterol. 16:377-384.

85. Jodal, M., Wingren, U., Jansson, M., Heidemann, M., and Lundgren, O. 1993. Nerve involvement in fluid transport in the inflamed rat jejunum. Gut. 34:1526-1530.

86. Castagliuolo, I., et al. 1994. Neuronal involvement in the intestinal effects of Clostridium difficile toxin $\mathrm{A}$ and Vibrio cholerae enterotoxin in rat ileum. Gastroenterology. 107:657-665.

87. Ball, J.M., Mitchell, D.M., Gibbons, T.F., and Parr, R.D. 2005. Rotavirus NSP4: a multifunctional viral enterotoxin. Viral Immunol. 18:27-40.

88. Beau, I., Cotte-Laffitte, J., Geniteau-Legendre, M., Estes, M.K., and Servin, A.L. 2007. An NSP4-dependant mechanism by which rotavirus impairs lactase enzymatic activity in brush border of human enterocyte-like Caco-2 cells. Cell Microbiol. 9:2254-2266.

89. Sansonetti, P.J., and Di Santo, J.P. 2007. Debugging how bacteria manipulate the immune response. Immunity. 26:149-161.

90. Sansonetti, P.J., Arondel, J., Cavaillon, J.M., and Huerre, M. 1995. Role of interleukin-1 in the pathogenesis of experimental shigellosis. J. Clin. Invest. 96:884-892.

91. Hecht, G. 2001. Microbes and microbial toxins: paradigms for microbial-mucosal interactions. VII. Enteropathogenic Escherichia coli: physiological alterations from an extracellular position. Am. J. Physiol. Gastrointest. Liver Physiol. 281:G1-G7.

92. Troeger, H., Schneider, T., Epple, H., Zeitz, M., and Schulzke, J.D. 2008. Diarrheal mechanisms of human norovirus infection. Gastroenterology. In press.

93. Gill, R.K., et al. 2007. Mechanism underlying inhibition of intestinal apical $\mathrm{Cl} / \mathrm{OH}$ exchange following infection with enteropathogenic E. coli. J. Clin. Invest. 117:428-437.

94. Haque, R., et al. 2007. Multiplex real-time PCR assay for detection of Entamoeba histolytica, Giardia intestinalis, and Cryptosporidium spp. Am.J. Trop. Med. Hyg. 76:713-717.

95. Logan, C., O'Leary, J.J., and O'Sullivan, N. 2007. Real-time reverse transcription PCR detection of norovirus, sapovirus and astrovirus as causative agents of acute viral gastroenteritis. J. Virol. Methods. 146:36-44.

96. Samie, A., Obi, C.L., Tzipori, S., Weiss, L.M., and Guerrant, R.L. 2007. Microsporidiosis in South Africa: PCR detection in stool samples of HIV-positive and HIV-negative individuals and school children in Vhembe district, Limpopo Province. Trans. R. Soc. Trop. Med. Hyg. 101:547-554.

97. Samie, A., Obi, C.L., Barrett, L.J., Powell, S.M., and Guerrant, R.L. 2007. Prevalence of Campylobacter species, Helicobacter pylori and Arcobacter species in stool samples from the Venda region, Limpopo, South Africa: studies using molecular diagnostic methods. J. Infect. 54:558-566.

98. ten Hove, R., et al. 2007. Detection of diarrhoeacausing protozoa in general practice patients in The Netherlands by multiplex real-time PCR. Clin. Microbiol. Infect. 13:1001-1007.

99. Samie, A., Obi, C.L., Dillingham, R., Pinkerton, R.C., and Guerrant, R.L. 2007. Enteroaggregative Escherichia coli in Venda, South Africa: distribution of virulence-related genes by multiplex polymerase chain reaction in stool samples of human immunodeficiency virus (HIV)-positive and HIVnegative individuals and primary school children. Am. J. Trop. Med. Hyg. 77:142-150.

100.Nataro, J.P., et al. 2006. Diarrheagenic Escherichia coli infection in Baltimore, Maryland, and New Haven, Connecticut. Clin. Infect. Dis. 43:402-407.

101. Ochoa, T.J., et al. 2006. Effect of lactoferrin on enteroaggregative E. coli (EAEC). Biochem. Cell Biol. 84:369-376.

102.Guerrant, R.L., et al. 1992. Measurement of fecal lactoferrin as a marker of fecal leukocytes. J Clin. Microbiol. 30:1238-1242.

103.Greenberg, D.E., Jiang, Z.D., Steffen, R., Verenker, M.P., and DuPont, H.L. 2002. Markers of inflammation in bacterial diarrhea among travelers, with a focus on enteroaggregative Escherichia coli pathogenicity. J. Infect. Dis. 185:944-949.

104.Kane, S.V., et al. 2003. Fecal lactoferrin is a sensitive and specific marker in identifying intestinal inflammation. Am. J. Gastroenterol. 98:1309-1314.

105.Venkataraman, S., Ramakrishna, B.S., Kang, G., Rajan, D.P., and Mathan, V.I. 2003. Faecal lactoferrin as a predictor of positive faecal culture in south Indian children with acute diarrhoea. Ann. Trop. Paediatr. 23:9-13.

106.D'Inca, R., et al. 2007. Calprotectin and lactoferrin in the assessment of intestinal inflammation and organic disease. Int. J. Colorectal Dis. 22:429-437.

107. Scarpa, M., et al. 2007. Fecal lactoferrin and calprotectin after ileocolonic resection for Crohn's disease. Dis. Colon Rectum. 50:861-869.

108. Amati, L., et al. 2006. New insights into the biologi$\mathrm{cal}$ and clinical significance of fecal calprotectin in inflammatory bowel disease. Immunopharmacol. Immunotoxicol. 28:665-681.

109.Lunn, P.G. 2000. The impact of infection and nutrition on gut function and growth in childhood. Proc. Nutr. Soc. 59:147-154.

110.Haeney, M.R., Culank, L.S., Montgomery, R.D., and Sammons, H.G. 1978. Evaluation of xylose absorption as measured in blood and urine: a one-hour blood xylose screening test in malabsorption. Gastroenterology. 75:393-400.

111.Lunn, P.G., Northrop-Clewes, C.A., and Downes, R.M. 1991. Intestinal permeability, mucosal injury, and growth faltering in Gambian infants. Lancet. 338:907-910.

112.Calain, P., et al. 2004. Can oral cholera vaccination play a role in controlling a cholera outbreak? Vaccine. 22:2444-2451.

113.Lucas, M.E., et al. 2005. Effectiveness of mass oral cholera vaccination in Beira, Mozambique. $N$. Engl. J. Med. 352:757-767.

114. Murphy, T.V., et al. 2001. Intussusception among infants given an oral rotavirus vaccine. N. Engl. J. Med. 344:564-572.

115.Ruiz-Palacios, G.M., et al. 2006. Safety and efficacy of an attenuated vaccine against severe rotavirus gastroenteritis. N. Engl. J. Med. 354:11-22.

116. Vesikari, T., et al. 2006. Safety and efficacy of a pentavalent human-bovine (WC3) reassortant rotavirus vaccine. N. Engl. J. Med. 354:23-33.

117. Lin, F.Y., et al. 2001. The efficacy of a Salmonella typhi Vi conjugate vaccine in two-to-five-year-old children. N. Engl. J. Med. 344:1263-1269.

118. Mai, N.L., et al. 2003. Persistent efficacy of Vi conjugate vaccine against typhoid fever in young children. N. Engl. J. Med. 349:1390-1391.

119.Kirkpatrick, B.D., et al. 2006. Evaluation of Salmonella enterica serovar Typhi (Ty2 aroC-ssaV-) M01ZH09, with a defined mutation in the Salmonella pathogenicity island 2, as a live, oral typhoid vaccine in human volunteers. Vaccine. 24:116-123.

120.Tacket, C.O., et al. 2000. Phase 2 clinical trial of attenuated Salmonella enterica serovar typhi oral live vector vaccine CVD 908-htrA in U.S. volunteers. Infect. Immun. 68:1196-1201.

121.Tacket, C.O., Pasetti, M.F., Sztein, M.B., Livio, S., and Levine, M.M. 2004. Immune responses to an oral typhoid vaccine strain that is modified to constitutively express Vi capsular polysaccharide. J. Infect. Dis. 190:565-570.

122.Hohmann, E.L., Oletta, C.A., Killeen, K.P., and Miller, S.I. 1996. phoP/phoQ-deleted Salmonella typhi (Ty800) is a safe and immunogenic single- dose typhoid fever vaccine in volunteers. J. Infect. Dis. 173:1408-1414.

123. Qadri, F., et al. 2007. Peru-15, a live attenuated oral cholera vaccine, is safe and immunogenic in Bangladeshi toddlers and infants. Vaccine. 25:231-238.

124.Garcia, L., et al. 2005. The vaccine candidate Vibrio cholerae 638 is protective against cholera in healthy volunteers. Infect. Immun. 73:3018-3024.

125.Orr, N., et al. 2005. Community-based safety, immunogenicity, and transmissibility study of the Shigella sonnei WRSS1 vaccine in Israeli volunteers. Infect. Immun. 73:8027-8032.

126. Kotloff, K.L., et al. 2007. Safety and immunogenicity of CVD 1208S, a live, oral $\triangle$ guaBA $\Delta$ sen $\Delta$ set Shigella flexneri 2 a vaccine grown on animal-free media. Hum. Vaccin. 3:268-275.

127. Katz, D.E., et al. 2004. Two studies evaluating the safety and immunogenicity of a live, attenuated Shigella flexneri 2a vaccine (SC602) and excretion of vaccine organisms in North American volunteers. Infect. Immun. 72:923-930.

128.Levine, M.M., Kotloff, K.L., Barry, E.M., Pasetti, M.F., and Sztein, M.B. 2007. Clinical trials of Shigella vaccines: two steps forward and one step back on a long, hard road. Nat. Rev. Microbiol. 5:540-553.

129. Cohen, D., et al. 1997. Double-blind vaccine-controlled randomised efficacy trial of an investigational Shigella sonnei conjugate vaccine in young adults. Lancet. 349:155-159.

130.Oaks, E.V., and Turbyfill, K.R. 2006. Development and evaluation of a Shigella flexneri $2 \mathrm{a}$ and S. sonnei bivalent invasin complex (Invaplex) vaccine. Vaccine. 24:2290-2301.

131. Fries, L.F., et al. 2001. Safety and immunogenicity of a proteosome-Shigella flexneri 2a lipopolysaccharide vaccine administered intranasally to healthy adults. Infect. Immun. 69:4545-4553.

132.McKenzie, R., et al. 2006. Safety and immunogenicity of an oral, inactivated, whole-cell vaccine for Shigella sonnei: preclinical studies and a Phase I trial. Vaccine. 24:3735-3745.

133.Xu, D.Q., Cisar, J.O., Osorio, M., Wai, T.T., and Kopecko, D.J. 2007. Core-linked LPS expression of Shigella dysenteriae serotype $1 \mathrm{O}$-antigen in live Salmonella Typhi vaccine vector Ty21a: preclinical evidence of immunogenicity and protection. Vaccine. 25:6167-6175.

134.Savarino, S.J., et al. 2003. Efficacy of an oral inactivated whole-cell enterotoxigenic E. coli/cholera toxin B subunit vaccine in Egyptian infants [abstract]. In The 6th Annual Conference on Vaccine Research. June 22-25. Arlington, Virginia, USA. National Foundation for Infectious Diseases. S11.

135.Daley, A., et al. 2007. Genetically modified enterotoxigenic Escherichia coli vaccines induce mucosal immune responses without inflammation. Gut. 56:1550-1556.

136. Barry, E.M., Wang, J., Wu, T., Davis, T., and Levine, M.M. 2006. Immunogenicity of multivalent Shigella-ETEC candidate vaccine strains in a guinea pig model. Vaccine. 24:3727-3734.

137. McKenzie, R., et al. 2007. Transcutaneous immunization with the heat-labile toxin (LT) of enterotoxigenic Escherichia coli (ETEC): protective efficacy in a double-blind, placebo-controlled challenge study. Vaccine. 25:3684-3691.

138. Tacket, C.O., Sztein, M.B., Losonsky, G.A., Wasserman, S.S., and Estes, M.K. 2003. Humoral, mucosal, and cellular immune responses to oral Norwalk virus-like particles in volunteers. Clin. Immunol. 108:241-247.

139.Scott, D.A. 1997. Vaccines against Campylobacter jejuni. J. Infect. Dis. 176(Suppl. 2):S183-S188.

140.Sougioultzis, S., et al. 2005. Clostridium difficile toxoid vaccine in recurrent $C$. difficile-associated diarrhea. Gastroenterology. 128:764-770.

141.Boullier, S., et al. 2003. Genetically engineered enteropathogenic Escherichia coli strain elicits a 
specific immune response and protects against a virulent challenge. Microbes Infect. 5:857-867.

142. Houpt, E., et al. 2004. Prevention of intestinal amebiasis by vaccination with the Entamoeba histolytica Gal/GalNac lectin. Vaccine. 22:611-617.

143.Jenkins, M.C. 2004. Present and future control of cryptosporidiosis in humans and animals. Expert Rev. Vaccines. 3:669-671.

144. He, H., et al. 2004. The humoral and cellular immune responses in mice induced by DNA vaccine expressing the sporozoite surface protein of Cryptosporidium parvum. DNA Cell Biol. 23:335-339.

145.Konadu, E.Y., et al. 2000. Phase 1 and phase 2 studies of Salmonella enterica serovar paratyphi A $\mathrm{O}$-specific polysaccharide-tetanus toxoid conjugates in adults, teenagers, and 2- to 4-year-old children in Vietnam. Infect. Immun. 68:1529-1534.

146. Thillainayagam, A.V., Hunt, J.B., and Farthing, M.J. 1998. Enhancing clinical efficacy of oral rehydration therapy: is low osmolality the key? Gastroenter ology. 114:197-210.

147. Rao, M.C. 2004. Oral rehydration therapy: new explanations for an old remedy. Annu. Rev. Physiol. 66:385-417.

148. Binder, H.J., and Mehta, P. 1990. Characterization of butyrate-dependent electroneutral $\mathrm{Na}-\mathrm{Cl}$ absorption in the rat distal colon. Pflugers Arch. 417:365-369.

149. Raghupathy, P., et al. 2006. Amylase-resistant starch as adjunct to oral rehydration therapy in children with diarrhea.J Pediatr. Gastroenterol. Nutr. 42:362-368.

150.Ramakrishna, B.S., et al. 2000. Amylase-resistant starch plus oral rehydration solution for cholera. N. Engl. J. Med. 342:308-313.

151. Ramakrishna, B.S., et al. 2008. A randomized controlled trial of glucose versus amylase resistant starch in hypo-osmolar oral rehydration solution for adult acute dehydrating diarrhea. PLos ONE. 3:e1587.

152.Sazawal, S., et al. 1995. Zinc supplementation in young children with acute diarrhea in India. N. Engl. J. Med. 333:839-844.

153. Bhatnagar, S., et al. 2004. Zinc with oral rehydration therapy reduces stool output and duration of diarrhea in hospitalized children: a randomized controlled trial. J Pediatr. Gastroenterol. Nutr. 38:34-40.

154.Hoque, K.M., and Binder, H.J. 2006. Zinc in the treatment of acute diarrhea: current status and assessment. Gastroenterology. 130:2201-2205.

155.Hoque, K.M., Rajendran, V.M., and Binder, H.J. 2005. Zinc inhibits cAMP-stimulated $\mathrm{Cl}$ secretion via basolateral K-channel blockade in rat ileum. $A m$. J. Physiol. Gastrointest. Liver Physiol. 288:G956-G963.

156.DeSesso, J.M., and Jacobson, C.F. 2001. Anatomical and physiological parameters affecting gastrointestinal absorption in humans and rats. Food Chem. Toxicol. 39:209-228.

157. Vanderhoof, J.A., and Young, R.J. 2003. Enteral and parenteral nutrition in the care of patients with short-bowel syndrome. Best. Pract. Res. Clin. Gastroenterol. 17:997-1015.

158.Lima, A.A., Soares, A.M., Freire Júnior, J.E., and Guerrant, R.L. 1992. Cotransport of sodium with glutamine, alanine and glucose in the isolated rabbit ileal mucosa. Braz. J. Med. Biol. Res. 25:637-640.

159.Blikslager, A., Hunt, E., Guerrant, R., Rhoads, M., and Argenzio, R. 2001. Glutamine transporter in crypts compensates for loss of villus absorption in bovine cryptosporidiosis. Am. J. Physiol. Gastrointest. Liver Physiol. 281:G645-G653.

160.Lima, N.L., et al. 2007. Wasting and intestinal barrier function in children taking alanyl-glutaminesupplemented enteral formula. J Pediatr. Gastroen- terol. Nutr. 44:365-374.

161.Bushen, O.Y., et al. 2004. Diarrhea and reduced levels of antiretroviral drugs: improvement with glutamine or alanyl-glutamine in a randomized controlled trial in northeast Brazil. Clin. Infect Dis 38:1764-1770.

162. Carneiro-Filho, B.A., Bushen, O.Y., Brito, G.A., Lima, A.A., and Guerrant, R.L. 2003. Glutamine analogues as adjunctive therapy for infectious diarrhea. Curr. Infect. Dis. Rep. 5:114-119.

163.van Loon, F.P., et al. 1996. The effect of L-glutamine on salt and water absorption: a jejunal perfusion study in cholera in humans. Eur. J. Gastroenterol. Hepatol. 8:443-448.

164. Ribeiro, J.H., et al. 1994. Treatment of acute diarrhea with oral rehydration solutions containing glutamine. J Am. Coll. Nutr. 13:251-255.

165.Amin, H.J., et al. 2002. Arginine supplementation prevents necrotizing enterocolitis in the premature infant. J. Pediatr. 140:425-431.

166. Ottenhoff, T.H., et al. 2002. Genetics, cytokines and human infectious disease: lessons from weakly pathogenic mycobacteria and salmonellae. Nat. Genet. 32:97-105.

167. Dunstan, S.J., et al. 2001. Genes of the class II and class III major histocompatibility complex are associated with typhoid fever in Vietnam. J. Infect. Dis. 183:261-268.

168. Mohamed, J.A., et al. 2007. A novel single-nucleotide polymorphism in the lactoferrin gene is associated with susceptibility to diarrhea in North American travelers to Mexico. Clin. Infect. Dis. 44:945-952.

169. The Wellcome Trust Case Control Consortium. 2007. Genome-wide association study of 14,000 cases of seven common diseases and 3,000 shared controls. Nature. 447:661-678. 